\title{
Implementing Herpetofaunal Inventory and Monitoring Efforts on Corps of Engineers Project Lands
}

Michael P. Guilfoyle

May 2010

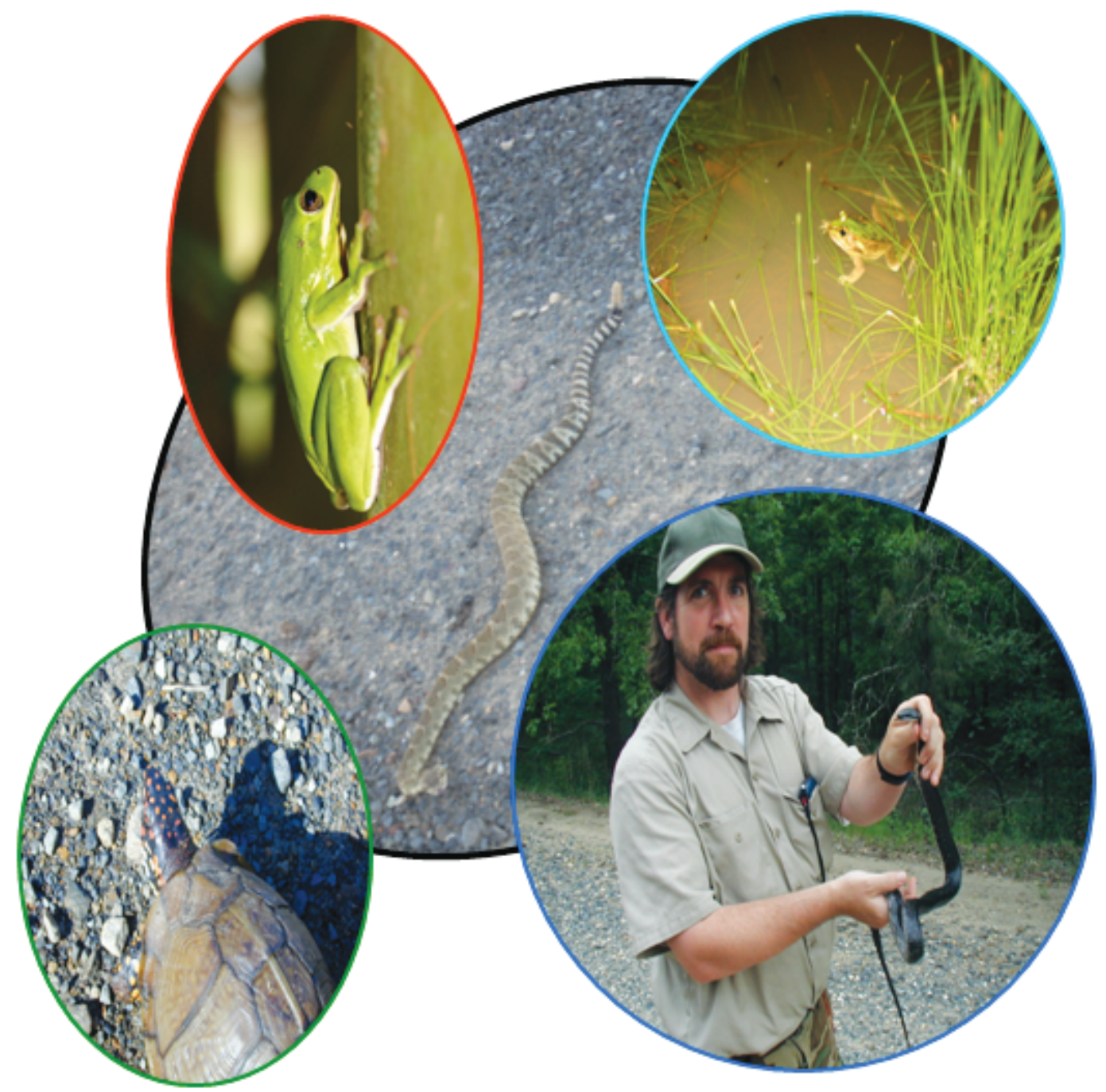




\section{Implementing Herpetofaunal Inventory and Monitoring Efforts on Corps of Engineers Project Lands}

Michael P. Guilfoyle

Environmental Laboratory

U.S. Army Engineer Research and Development Center

3909 Halls Ferry Road

Vicksburg, MS 39180-6199

Final report

Approved for public release; distribution is unlimited.

Prepared for Headquarters, U.S. Army Corps of Engineers

Washington, DC 20314-1000 


\begin{abstract}
Herpetofaunal species include reptiles and amphibians such as snakes, lizards, turtles, alligators, frogs, and salamanders. These animals are recognized for their valuable contributions to the nation's natural diversity and their important role in ecological systems. The Corps of Engineers is engaged in increasing efforts to inventory and monitor these animals on project lands because of their sensitivity to human land-use disturbances and contaminants and for legal and regulatory compliance. This technical report provides an overview of standard methods to inventory and monitor these organisms, and summarizes the number and distribution of federal/state listed threatened and endangered reptiles and amphibians documented within seven Corps Divisions and associated Districts. An introduction to setting goals and objectives is provided, followed by brief descriptions of the primary techniques for attaining Level II inventories on Corps of Engineer project lands, or other areas under Corps jurisdiction. The techniques focus on terrestrial and aquatic reptiles and amphibians and include (1) Time/ Area-constrained Searches, (2) Road Surveys, (3) Coverboard Arrays, (4) Pitfall traps and Terrestrial Drift Fences, (5) Seining, Dipnetting, and Sweep Samples, (6) Auditory Surveys, and (7) Basking Surveys and Traps. Finally, methods to inventory other notable species, including sea turtles, alligators, and crocodiles are summarized.
\end{abstract}

DISCLAIMER: The contents of this report are not to be used for advertising, publication, or promotional purposes. Citation of trade names does not constitute an official endorsement or approval of the use of such commercial products. All product names and trademarks cited are the property of their respective owners. The findings of this report are not to be construed as an official Department of the Army position unless so designated by other authorized documents. 


\section{Contents}

Figures and Tables..........................................................................................................................................

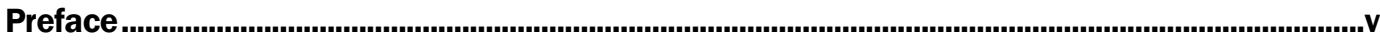

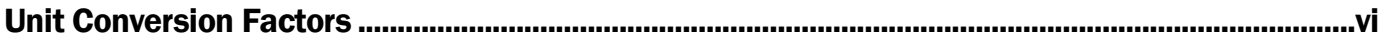

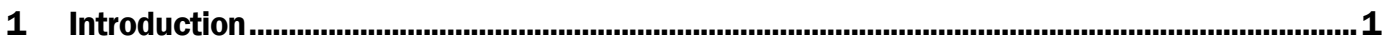

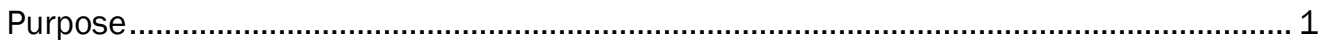

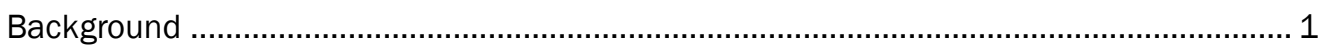

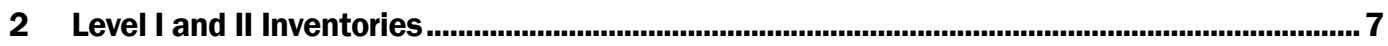

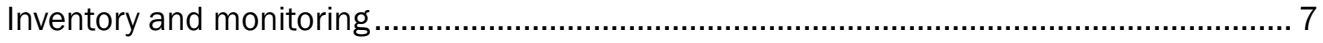

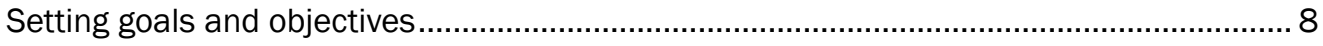

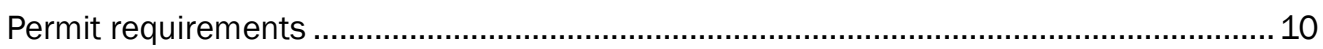

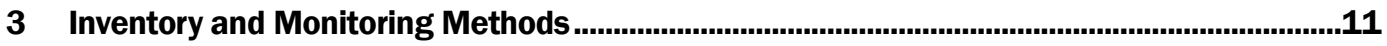

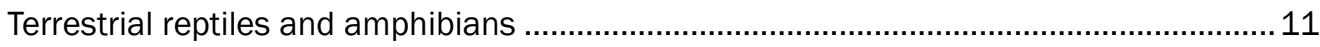

Time/area-constrained searches............................................................................. 11

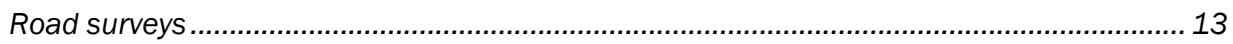

Coverboard arrays ...................................................................................................... 14

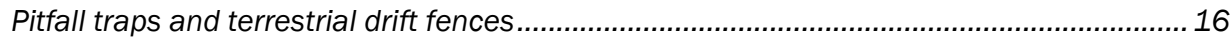

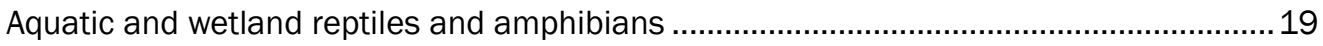

Seining, dipnetting and sweep samples ......................................................................... 19

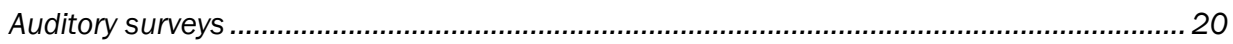

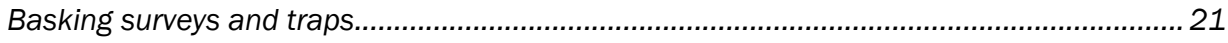

Other notable inventory methods for specific target species.............................................. 22

4 Marking Techniques for Captured Herpetofaunal Species ........................................................25

5 Summary

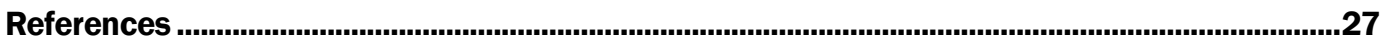

Appendix A: Common and Scientific Names.........................................................................32

Report Documentation Page 


\section{Figures and Tables}

\section{Figures}

Figure 1. Many reptiles and amphibians, including the tiger salamander above, are highly dependent on wetland and aquatic habitats, especially during the larval and juvenile portions of their life cycle....

Figure 2. The little striped whiptail is an abundant and widely distributed terrestrial reptile in the southwestern United States, may be detected during time/area-constrained searches, visual encounter surveys, and road surveys

Figure 3. Time-constrained area searches along streams and other riparian habitats are a common approach to surveying for the presence of aquatic reptiles and amphibians, particularly salamanders

Figure 4. In many portions of the United States, many turtles, including this eastern box turtle, may be easily detected during road surveys because of their limited mobility

Figure 5. A pitfall trap and associated drift fence station; one of multiple stations established at the Cabrillo National Monument, Point Loma, CA, as part of a long-term herpetofaunal community monitoring program

Figure 6. A typical pitfall trap and drift fence station used to capture terrestrial reptiles and amphibians.

Figure 7. An example of a wire mesh funnel trap, typically placed along a drift fence to capture large snakes, or other species that may be missed by the pitfall traps

Figure 8. The two-toed amphiuma is a large aquatic amphibian present in many pond and lake habitats in the southeastern United States

Figure 9. The green treefrog is a highly vocal species easily detected through auditory surveys in the eastern United States.

Figure 10. The Ringed Map Turtle is a riverine turtle species that can be best detected by conducting basking surveys along rivers

Figure 11. The American crocodile is a threatened reptile monitored by funding from the Corps of Engineers in the southern Everglades, FL

Figure 12. Examples of marking techniques for snakes, turtles, lizards, and some amphibians that may be used to identify recaptures during monitoring of reptiles and amphibians with pit fall traps and associated drift fences, or other methods.

\section{Table}

Table 1. Corps Divisions and associated Districts with federally and/or state listed threatened, endangered or sensitive reptiles and amphibians that have been reported or may potentially occur on operational project lands within their District boundaries 


\section{Preface}

This work was conducted by the Environmental Laboratory (EL), U.S. Army Engineer Research and Development Center (ERDC), for the Corps of Engineers Ecosystem Management and Restoration Research Program (EMRRP). The work unit title was "Natural Resource Inventories for Special Status Species on Corps Operating Projects." Michael P. Guilfoyle wrote this report, Chester O. Martin was the Principal Investigator for the work unit, and the EMRRP Program Manager was Glenn Rhett, EL.

The Corps of Engineers Stewardship Advisory Team (SAT) provided technical support for all aspects of the natural resources inventory work unit. Thanks go out to all members of the SAT, especially to J eff Krause, Baltimore District, for providing technical support. Photographs were provided by Doug Burkett, Dena Dickerson, and Michael P. Guilfoyle. Other photographs are public domain and were obtained online; persons credited retain all copyrights to these photos and use of these photographs is for research and education purposes only. This technical report was reviewed by Dena D. Dickerson, Chester O. Martin, and Dr. Eric R. Britzke, EL.

This report was prepared under the general supervision of Antisa Webb, Chief, Ecological Resources Branch, EL; Dr. Edmund Russo, Chief, Ecological Evaluation and Engineering Division, EL; and Dr. Beth Fleming, Director, EL.

COL Gary E. J ohnston was Commander and Executive Director of ERDC. Dr. J effery P. Holland was Director. 


\section{Unit Conversion Factors}

Multiply

inches
By

0.0254
To Obtain

meters 


\section{Introduction}

\section{Purpose}

This technical report is a product of the Ecosystem Management and Restoration Research Program (EMRRP) work unit titled "Natural Resource Inventories for Special Status Species on Corps Operating Projects." The objective of the work unit is to provide guidelines for conducting Level I and II inventories on Corps projects (Martin et al. 2006) with emphasis on methods that apply to a variety of animals. The recent focus on ecosystem management and inclusion of nongame species in management plans has provided opportunities to improve the management of natural resources for many forest, grassland, wetland and aquatic reptiles and amphibians. The purpose of this technical report is to: (1) provide an overview of the importance of herpetofaunal communities on Corps projects (Figure 1), (2) identify important herpetofaunal inventory and monitoring objectives appropriate for Corps lands, and (3) outline and describe specific methods for surveying (Level II surveys) terrestrial and aquatic herpetofaunal communities under a variety of habitat conditions.

\section{Background}

Herpetofaunal species include reptiles (e.g., snakes, lizards, turtles and alligators) and amphibians (e.g., frogs, toads and salamanders). Most of these species have historically been overlooked by land managers as they were considered undesirable or even dangerous and were ignored or targeted for eradication. Improvements

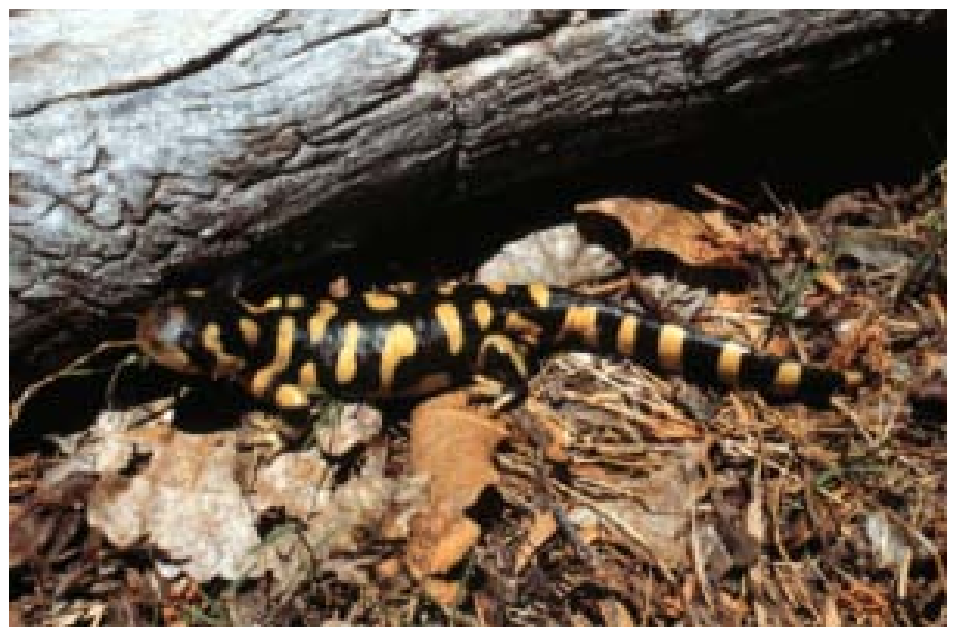

Figure 1. Many reptiles and amphibians, including the tiger salamander above, are highly dependent on wetland and aquatic habitats, especially during the larval and juvenile portions of their life cycle (photo by Doug Burkett).

in education and understanding have provided a greater appreciation for the value of these animals and the important role they play in ecological systems. Reptiles and amphibians often constitute the largest number and biomass of vertebrates present in riparian and wetland habitats 
(Maisonneuve and Rioux 2001; Goin et al. 1978) and are critical in the food chain as predators or prey species for other vertebrates and invertebrates (Goin et al. 1978). These animals are exothermic ('cold-blooded') and are dependent on specific features of the environment and associate behaviors to assist them in metabolic thermoregulation. Since many amphibians breathe through their skin, they depend on aquatic and/ or high moisture conditions. Reptiles require suitable areas to safely sunbathe to increase their metabolic rates to perform tasks of foraging, reproduction, escape from predators, etc. In most habitats, herpetofaunal diversity is often positively related to microhabitat diversity; which provides suitable environmental conditions for thermoregulation. Microhabitat diversity includes such features as soil depth and texture, presence of water, rocks, dead and live vegetation, rocks, and litter/ debris (J ones 1986). The extreme sensitivity of these animals to microhabitat conditions makes their population status and trends particularly useful for monitoring ecological health of a given area, plus they can provide insight into the impacts of pollution, habitat modification, and other human-related activities on natural populations.

Within the continental United States, there are approximately 260 species of reptiles and 200 species of amphibians (Graeter et al. 2008). Thirtyseven reptile species have been listed by the U.S. Fish and Wildlife Service (USFWS) as threatened or endangered (24 threatened/ 13 endangered) and 24 amphibians have also been listed (11 threatened/ 13 endangered) under the Endangered Species Act (USFWS 2008a). Two sources were used to determine the number of federally and/ or state listed herpetofaunal species on seven Corps Divisions and 30 associated Districts in the United States; the U.S. Army Corps of Engineers (USACE) and Threatened, Endangered and Sensitive Species website (USACE 2005), and the Corps Operations and Management Business Information List (OMBIL) Special Status Species Fiscal Reports (OMBIL 2008). From these lists, 22 federally listed species are noted ( 15 threatened/ 7 endangered), plus an additional 77 species and 15 subspecies listed by one or more states within a Corps' District jurisdiction are identified by Division and District in Table 1. Due to a lack of updated information on species distributions, the number of federal and state-listed species within Corps operational project lands is likely an underestimate. Moreover, many sensitive reptile and amphibian populations are currently experiencing long-term declines (Graeter et al. 2008) and additional listings are likely in the future. 
Table 1. Corps Divisions and associated Districts with federally and/or state listed threatened, endangered or sensitive reptiles and amphibians that have been reported or may potentially occur on operational project lands within their District boundaries (USACE 2005; OMBIL 2008). Common names provided: Scientific names of all reptile and amphibian species noted are listed in Appendix A.

\begin{tabular}{|c|c|}
\hline \multicolumn{2}{|r|}{ Great Lakes and Ohio River Division } \\
\hline Nashville District & $\begin{array}{l}\text { Flattened Musk TurtleFED-T, Alligator Snapping Turtles, Northern Coal Skinks, Southern Coal } \\
\text { Skinks, Scarlet Kingsnakes, Western Pigmy Rattlesnakes, Copperbelly Water SnakeFED-T, } \\
\text { Eastern Ribbon Snakes, Northern Pine Snakes, Cave Salamanders }\end{array}$ \\
\hline Huntington District & $\begin{array}{l}\text { Common Map Turtles, Eastern River Cooters, Scarlet Kingsnakes, Eastern Ribbon Snake, } \\
\text { Blanchard's Cricket Frogs, Northern Leopard Frogs, Cave Salamander, Green Salamanders, } \\
\text { Jefferson Salamanders, Smallmouth Salamanders, Wehrle's Salamanders }\end{array}$ \\
\hline Louisville District & $\begin{array}{l}\text { Blanding's Turtles, Eastern Box Turtles, Eastern Mud Turtles, Spotted Turtles, Eastern } \\
\text { Massasaugas, Timber Rattlesnakes, Copperbelly Water Snake, Kirtland's Snakes, Rough } \\
\text { Green Snakes, Smooth Green Snakes, Northern Crawfish Frogs, Four-toed Salamanders }\end{array}$ \\
\hline Pittsburgh District & Smooth Softshells, Timber Rattlesnake \\
\hline Buffalo District & Timber Rattlesnake \\
\hline \multicolumn{2}{|r|}{ Mississippi Valley Division } \\
\hline New Orleans District & Green Turtle FED-Eb, HawksbillFED-E, Atlantic RidleyFED-T, LoggerheadFED-T, American AlligatorFED-T \\
\hline Rock Island & Blanding's Turtle, Illinois Mud Turtles, Western Hognose Snakes \\
\hline St. Louis & $\begin{array}{l}\text { Alligator Snapping Turtle, Eastern River Cooter, Blanding's Turtle, Eastern Massasauga, } \\
\text { Timber Rattlesnake, Kirtland's Snake, Western Fox Snakes, Western Hognose Snakes, Great } \\
\text { Plains Rat Snakes, Illinois Chorus Frogs, Hellbenders }\end{array}$ \\
\hline St. Paul District & $\begin{array}{l}\text { Blanding's Turtle, Common Map Turtle, Common Snapping Turtles, False Map Turtles, } \\
\text { Ouachita Map Turtles, Smooth Softshells, Spiny Softshells, Northern Painted Turtles, Wood } \\
\text { Turtles, Slender Glass Lizards', Blanchard's Cricket Frog }\end{array}$ \\
\hline Vicksburg District & 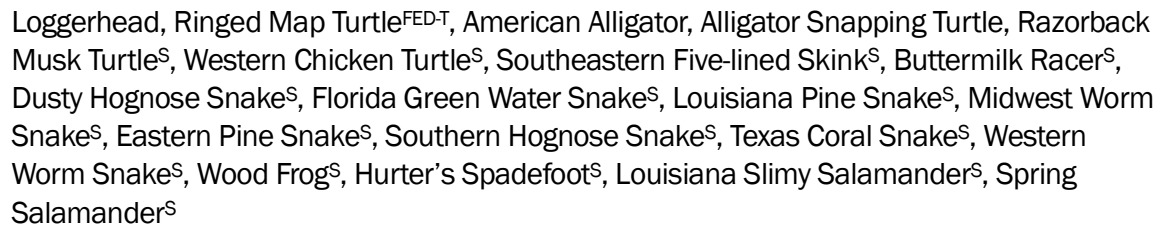 \\
\hline \multicolumn{2}{|r|}{ North Atlantic Division } \\
\hline Baltimore District & $\begin{array}{l}\text { Green Turtle, Hawksbill, Atlantic Ridley, LeatherbackFED-T, Loggerhead, Diamondback } \\
\text { Terrapins, Timber Rattlesnake }\end{array}$ \\
\hline New England District & $\begin{array}{l}\text { Green Turtle, Atlantic Ridley, Leatherback, Loggerhead, Diamondback Terrapin, Blanding's } \\
\text { Turtle, Eastern Box Turtle, Spotted Turtle, Wood Turtle, Eastern Hognose Snakes, Blue } \\
\text { Spotted Salamanders, Four-toed Salamander, Jefferson Salamander, Spring Salamander }\end{array}$ \\
\hline Norfolk District & $\begin{array}{l}\text { Atlantic Salt Marsh Snake FED-T, Timber Rattlesnake, Green Turtle, Hawksbill, Atlantic Ridley, } \\
\text { Leatherback, Loggerhead, Eastern Chicken Turtles, Barking Treefrogs', Mabee's } \\
\text { Salamanders, Oak Toads, Eastern Tiger Salamanders }\end{array}$ \\
\hline Philadelphia District & $\begin{array}{l}\text { Green Turtle, Hawksbill, Atlantic Ridley, Leatherback, Loggerhead, Bog Turtle }{ }^{\text {FED-T, }} \text {, Eastern } \\
\text { Redbelly Turtles, Midland Chorus Frogs }\end{array}$ \\
\hline
\end{tabular}




\begin{tabular}{|c|c|}
\hline \multicolumn{2}{|r|}{ Northwestern Division } \\
\hline Kansas City District & Great Plains Skinks, Northern Crawfish Frog, Wood Frog \\
\hline Omaha District & $\begin{array}{l}\text { Blanding's Turtle, False Map Turtle, Northwestern Pond Turtles, Eastern Hognose Snake, } \\
\text { Lined Snakes }\end{array}$ \\
\hline Portland District & $\begin{array}{l}\text { Northwestern Pond Turtle, Northern Painted Turtle, Prairie Rattlesnakes, Foothill Yellow- } \\
\text { legged Frogs, Northern Red-legged Frogs, Western Toads, Clouded Salamanders }\end{array}$ \\
\hline Seattle District & $\begin{array}{l}\text { Leatherback, Western Pond Turtles, Northern Alligator Lizards, Northern Leopard Frog, } \\
\text { Western Toad, Coeur d'Alene Salamanders }\end{array}$ \\
\hline Walla Walla District & $\begin{array}{l}\text { Northwestern Pond Turtle, Northern Painted Turtle, Western Pond Turtle, Northern Alligator } \\
\text { Lizard, Northern Sagebrush Lizards', Sagebrush Lizard's, Ringneck Snakes, Columbia Spotted } \\
\text { Frog', Northern Leopard Frog, Oregon Spotted Frog', Western Toad, Woodhouse's Toad's, } \\
\text { Coeur d'Alene Salamander }\end{array}$ \\
\hline \multicolumn{2}{|r|}{ South Atlantic Division } \\
\hline Charleston District & Green Turtle, Hawksbill, Atlantic Ridley, Leatherback, Loggerhead \\
\hline Jacksonville District & 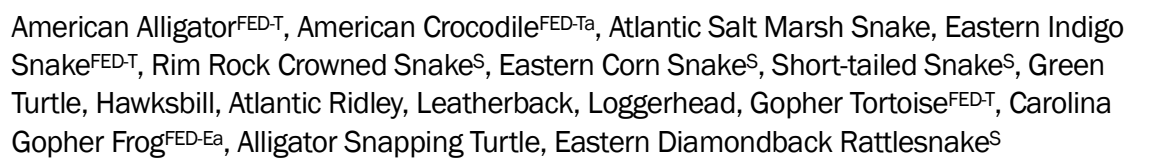 \\
\hline Mobile District & $\begin{array}{l}\text { Green Turtle, Hawksbill, Atlantic Ridley, Leatherback, Loggerhead, American Alligator, } \\
\text { Gopher Tortoise, Eastern Indigo Snake, Red Hills SalamanderFED-T }\end{array}$ \\
\hline Savannah District & $\begin{array}{l}\text { Green Turtle, Atlantic Ridley, Leatherback, Loggerhead, Bog Turtle, Coal Skinks, Green } \\
\text { Salamander }\end{array}$ \\
\hline Wilmington District & $\begin{array}{l}\text { American Alligator, Green Turtle, Hawksbill, Atlantic Ridley, Leatherback, Loggerhead, } \\
\text { Diamondback Terrapin }\end{array}$ \\
\hline \multicolumn{2}{|r|}{ South Pacific Division } \\
\hline Albuquerque District & Barking Frog \\
\hline Sacramento District & 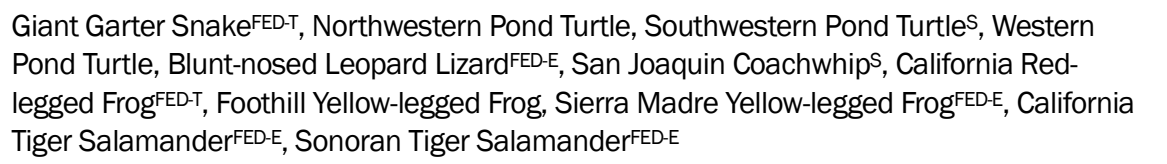 \\
\hline San Francisco District & Western Pond Turtle, Foothill Yellow-legged Frog, Northern Red-legged Frog \\
\hline \multicolumn{2}{|r|}{ Southwestern Division } \\
\hline Fort Worth District & $\begin{array}{l}\text { American Alligator, Alligator Snapping Turtle, Texas Horned Lizards, Timber Rattlesnake, } \\
\text { Louisiana Pine Snake, Scarlet Snake }\end{array}$ \\
\hline Galveston District & Green Turtle, Hawksbill, Atlantic Ridley, Loggerhead \\
\hline Little Rock District & American Alligator, Alligator Snapping Turtle \\
\hline Tulsa District & American Alligator \\
\hline \multicolumn{2}{|c|}{$\begin{array}{l}\text { FED-T Species federally listed as threatened. } \\
\text { FED-Ta Species federally listed as threatened in Florida. } \\
\text { FED-E Species federally listed as endangered. } \\
\text { FED-Ea Species federally listed as endangered in Alabama, Mississippi, and Louisiana. } \\
\text { FED-Eb Species federally listed as endangered in Florida; listed as threatened elsewhere. } \\
\text { S Species listed as threatened, endangered or sensitive by one or more states within the jurisdictional boundaries of a Corps' } \\
\text { District. }\end{array}$} \\
\hline
\end{tabular}


Worldwide, reptile and amphibian populations have experienced declines due to multiple factors including habitat loss and fragmentation, environmental contaminants, introduction of invasive species, harvesting, and disease outbreaks (Graeter et al. 2008). Many species are sensitive to disruptions in local habitat conditions that may alter availability of key features needed for thermoregulation, foraging, and reproductive purposes. Moreover, fragmentation may serve to isolate populations, compromising processes of immigration and emigration, leading to localized extinctions that may endanger whole populations. Herpetofaunal species, particularly amphibians, may be especially sensitive to contaminants including insecticides and herbicides from agricultural run-off, industrial effluent, road de-icing salt run-off, and untreated sewage waste. In some eastern mountain habitats, acid rain on streams has negatively impacted populations of hellbenders (see Appendix A for scientific names of reptiles and amphibians) (Gates et al. 1985). Numerous reptiles, including alligators and various snakes, have also shown documented impacts of accumulated toxins including organochlorine compounds, mercury, selenium, cadmium, and arsenic in their tissues (Hopkins et. al. 1999; Guillette and Gunderson 2001; Glennemeier and Begnoche 2002; Unrine et al. 2005).

Invasive species have contributed to the declines of some reptile and amphibian populations. For example, the introduced red fire ant (Solenopsis invicta) in the southeastern United States is known to inflict considerable mortality in eggs, young, and adults of many reptile and amphibian species (Allen et al. 1997). The introduction of predatory fish (e.g., brook trout (Salvelinus frontinalis)) and anurans to areas outside their original range (e.g., introduction of the bullfrog into western habitats) have decimated local amphibian populations. Numerous reptile and amphibian populations have been impacted by collection and harvesting of individuals for the pet trade, while harvesting of alligators and crocodiles for food and skin has historically caused population declines for these species, plus the practice of rattlesnake round-ups can have severe impacts on local snake populations.

Finally, global amphibian populations have been impacted by the pathogenic chytrid fungus (Batrachochytrium dendrobatidis). While this fungus has not caused any known extinction of amphibians in the United States, it is a common infection for many North American amphibians (Daszak et al. 2005). Amphibians are also susceptible to the iridovirus 
(Ranavirus sp.), which can cause large-scale die-offs by infection of larval and metamorphosing individuals (J ancovich et al. 1995). Both the gopher and desert tortoise are vulnerable to the contagious Upper Respiratory Disease (URTD) caused by the bacterium Mycoplasma agassizi (Smith et al. 1998). Numerous other freshwater turtles have been reported to be susceptible to infections that cause mortality through sloughing and thinning of the shell (Graeter et al. 2008). Parasites and other infections of snakes can be extensive, but are poorly understood.

The Corps of Engineers manages over 450 man-made lakes within the continental United States. In addition, the Corps has jurisdiction over approximately $38,600 \mathrm{~km}$ of inland navigation rivers. Corps reservoir projects encompass approximately 4.7 million ha of land and open water habitat, with the total shoreline length exceeding the entire coastline of the United States (Fischer and Hamilton 1999, 2001). These areas support high quality riparian habitats and associated terrestrial and wetland habitats along lakes and rivers, and constitute important year-round habitat for numerous reptiles and amphibians. The Corps was first authorized to manage these lands for wildlife, including herpetofaunal communities, with the passage of Section 4 of the Flood Control Act of 1944 (U.S. Congress 1944). As with other federal agencies, the Corps is mandated to inventory and assess their lands for presence of threatened and endangered species. Moreover, Engineer Regulation (ER) 1130-2-540, Section 2-2.c(1) (Department of the Army 1996) mandates that the Corps conduct natural resources inventories to facilitate best management operations on project lands. 


\section{Level I and II Inventories}

Natural Resource Level I Inventories for Corps projects are defined as inventories conducted to provide baseline species occurrence data for Master Plan and Operational Management Plan development (Krause et al. 2004; Martin et al. 2006). Level II inventories involve the application of broad-based inventory methods to determine the occurrence and distributional status of selected species or species groups (e.g., songbirds, small mammals, bats, etc.). Level II inventories can then be followed by regular monitoring of selected species or species groups to determine population trends, or more specific methodologies can be selected for particular situations that require scientifically verifiable surveys of federally listed threatened and endangered species (Martin et al. 2006).

The remainder of this technical note will focus on methods to conduct Level II inventories on Corps lands. When establishing and implementing Level II inventories for herpetofaunal communities, it is recommended that managers identify specific goals, objectives, and methods. The Partners in Amphibian and Reptile Conservation (PARC) is a national coalition of state and federal agencies, museums, pet trade industries, conservation agencies, universities, zoos, environmental consultants, and others, all dedicated to the protection and conservation of native herpetofaunal species and associated habitat. PARC has produced a detailed volume on methods of inventory and monitoring of herpetofaunal communities applicable to the United States and Canada (Graeter et al. 2008); much of this technical note summaries methods from this document. In addition, the U.S. Geological Survey (USGS) has established the Amphibian Research and Monitoring Initiative (ARMI) to address issues and standardize methods for the monitoring and conservation of U.S. amphibian populations (http://armi.usgs.gov/) (USGS 2008). It is recommended that Corps projects establish herpetofaunal surveys consistent with approaches detailed in the PARC and ARMI publications.

\section{Inventory and monitoring}

Inventory and monitoring efforts are essential elements in the management and conservation of natural resources on Corps projects. Inventories provide baseline information that allows managers to determine the presence or absence and distribution of rare or sensitive species, including 
any species listed as endangered or threatened at the state or federal level. Once an initial inventory has been completed, the need for monitoring can be assessed. Monitoring population status involves the repeated, regular collection and analysis of population metrics. Data on population trends are critical if managers are to identify any species experiencing significant changes in abundance or distribution. Any verified changes in a target species' abundance and/ or distribution may lead to development of management strategies designed to promote conservation. Management options may also entail applied research to address specific questions about a species' basic biology/ ecology and any potential impacts of specific management actions. Therefore, conservation efforts start with an inventory, followed by monitoring and management, and identification of potential research (Graeter et al. 2008).

\section{Setting goals and objectives}

Due to specific life history characteristics, there are seasonal differences in the ability to detect many reptiles and amphibians. Many species are difficult to detect because of their nocturnal habits, or their tendency to shelter under rocks, logs and other debris. However, once they emerge and move to breeding areas, they can be easier to document. Detection of some species may be greatly enhanced if surveys occur after rain events; so survey efforts may be uneven, which potentially may compromise the use of some analytical methods required to detect changes in population status. Many different species inhabiting an area may have varying seasonal periods of activity when they are best detected, making survey efforts logistically difficult to schedule. Therefore, knowledge of the area to be inventoried and the life history traits of the animals likely to be found in an area, are essential before inventory and monitoring efforts can begin (Gibbons 2008).

In general, primary goals and objectives of conducting a herpetofaunal survey in an area include the following:

1. To produce a species list and the distribution of reptiles and amphibians in the various habitats.

2. To verify the presence/ absence of state or federally listed threatened, endangered, or sensitive species.

3. To provide baseline data on species presence and occupancy prior to implementation of some management or operational activity.

4. To identify species and habitats in need of further protection. 
5. To evaluate existing areas as habitat for reptiles and amphibians.

Once an initial inventory has been performed, a need for further monitoring may be determined with goals and objectives typically including the following:

1. To monitor population trends (relative abundance, population viability estimates) of selected species to determine status of the population(s) through time.

2. To determine the impacts of various management and operation activities on the availability of habitats and viability of selected populations.

3. To obtain information on the status of selected populations (e.g., habitat relationships) over time to devise strategies to improve population levels to meet explicit conservation goals, and to meet or exceed compliance of state and federal regulations for protection of listed species.

Application of standardized and repeatable methods is essential in producing meaningful data that can be compared across habitats and years. Specifics of research design, including whether researchers use a randomized sampling design (sample units distributed randomly across a specific area or habitat type) or stratified random design (sample units distributed in regular intervals through an area or specific habitat), and other concerns such as number of sampling units, number of organisms detected, collected, or sampled, are detailed in other sources (e.g., Graeter et al. 2008; Heyer et al. 1994; Skalski and Robson 1992; Krebs 1989; Davis 1982). Details of standardized inventory and monitoring methods for reptiles and amphibians can be found in Graeter et al. (2008); Heyer et al. (1994); and the USGS ARMI website (http://armi.usgs.gov/index.asp) (USGS 2008). Furthermore, accurate identification of detected reptiles and amphibians is necessary. Numerous regional field guides are available (e.g., Stebbins 1985; Conant and Collins 1998), plus many states have published field guides for local herpetofaunal species. Additional sources for herpetofaunal identification are listed in Graeter et al. (2008).

Methods vary in their ability to document species presence or population status. In order to develop a comprehensive inventory or monitoring of herpetofaunal species of an area, typically a suite of different methods may be needed. Because of the large number of different methods used to sample various herpetofaunal species, this technical note will summarize methods typically used to sample a suite of different species (with the 
exception of some turtles, alligators, and crocodiles); these are the most likely methods to be used by most Corps projects. The following methods are described under headings for (1) terrestrial reptiles and amphibians, and (2) aquatic and wetland reptiles and amphibians.

\section{Permit requirements}

If inventory and/ or monitoring of herpetofaunal populations will include efforts to capture, collect, tag, or mark individuals, state or federal permits will likely be required. Federal permits will be required if any federally listed species are to be captured or handled. Some states or national parks and wildlife refuges may require additional permits or the completion of specific training courses. Applicants should list all field personnel involved with collection and handling of animals, plus some applications may require a detailed background check, assessment of technical qualifications, and references from professionals knowledgeable of the applicant's expertise (Martin 2009). Collection permits can take weeks or months to procure; therefore, applications should be submitted to the appropriate state or federal agency well in advance of the scheduled sampling effort. Procurement of collection permits may require additional costs. Usually the costs are minimal, but if extensive training is required, costs may become significant and should be included during the project development. Once the necessary permits have been obtained, care must be taken to follow all regulations during sampling efforts, and the researcher must be sure to report all inventory data as stated by the permit guidelines. 


\section{Inventory and Monitoring Methods}

\section{Terrestrial reptiles and amphibians}

\section{Time/area-constrained searches}

Reptiles and amphibians can be sampled either by searching an area for a predetermined amount of time (time-constrained surveys), or by sampling animals in established standardized plots in specified areas (area-constrained surveys). Usually adult reptiles and amphibians are detected during time/ area searches and these searches are often focused on terrestrial or stream habitats (Figure 2).

Active searches for reptile and amphibian species in an area include overturning rocks, logs, ground litter and debris and other features of the habitat. All species detected are recorded, plus additional information on age and sex of individuals if possible. Surveyors must be careful to minimize damage to the habitat during these surveys and all rock and ground debris features must be returned to their original position after being sampled. Thirty-minute surveys per plot or area are typical for time-constrained areas searches (Graeter et al. 2008), but the

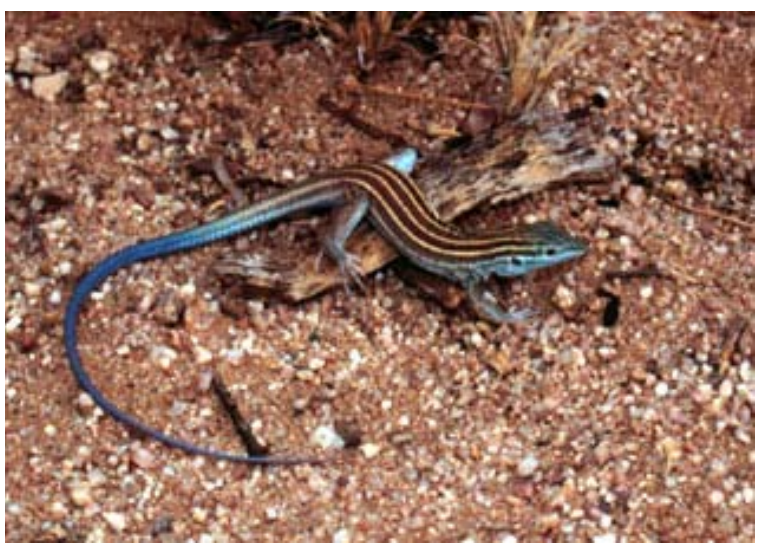

Figure 2. The little striped whiptail is an abundant and widely distributed terrestrial reptile in the southwestern United States, may be detected during time/area-constrained searches, visual encounter surveys, and road surveys (photo by Doug Burkett). actual time may be much longer if many individuals and/ or species are detected. In area-constrained searches, plot sizes to be sampled may be as small as $1 \mathrm{~m} \times 1 \mathrm{~m}$ or up to $50 \mathrm{~m} \times 50 \mathrm{~m}$. In some area searches of ponds or wetlands, a single pond may be the area of interest, and survey efforts may last many hours. Even in habitats/ regions where plot size is relatively small, high concentrations of species may take a few hours. While time/ area-constrained searches are often used to sample terrestrial and stream salamanders (Butts and McComb 2000; Bailey et al. 2004), they have been adapted for surveys involving frogs, lizards, and snakes; therefore, they are generally useful for documenting the herpetofaunal community of a given area (Graeter et al. 2008). 
A single short time/ area-constrained survey will not generate a complete inventory of the herpetofaunal community. Over the course of a year, multiple searches should take place in different seasons and different time blocks to account for differentiated species' activity patterns. Knowledge of herpetofaunal species within the general region will assist greatly in determining timing and frequency of time/ area-constrained surveys. The process of actively searching for animals (e.g., turning over logs and rocks), must be standardized and repeated consistently during the inventory period to make inferences about changes in abundance, species diversity and/ or observed distributions (Figure 3). When using consistent plot sizes for area-constrained searches, and sampling under a variety of different habitat, weather, and seasonal conditions, animal densities, abundance and distribution measures can be calculated, and the data can be used for long-term monitoring (Bailey et al. 2004; Graeter et al. 2008). It should be noted that time/ area-constrained surveys may require significant numbers of field technicians to cover multiple sites and areas. Regardless, the approach is generally simple, easy to implement, and less costly than other approaches. Variations of time/ area searches include the application of transects or quadrats. In areas with good visibility, managers may exclude any active search procedures (e.g., no turning over rocks or logs) and rely on simple visual detection of individuals (visual encounter surveys) (Graeter et al. 2008).

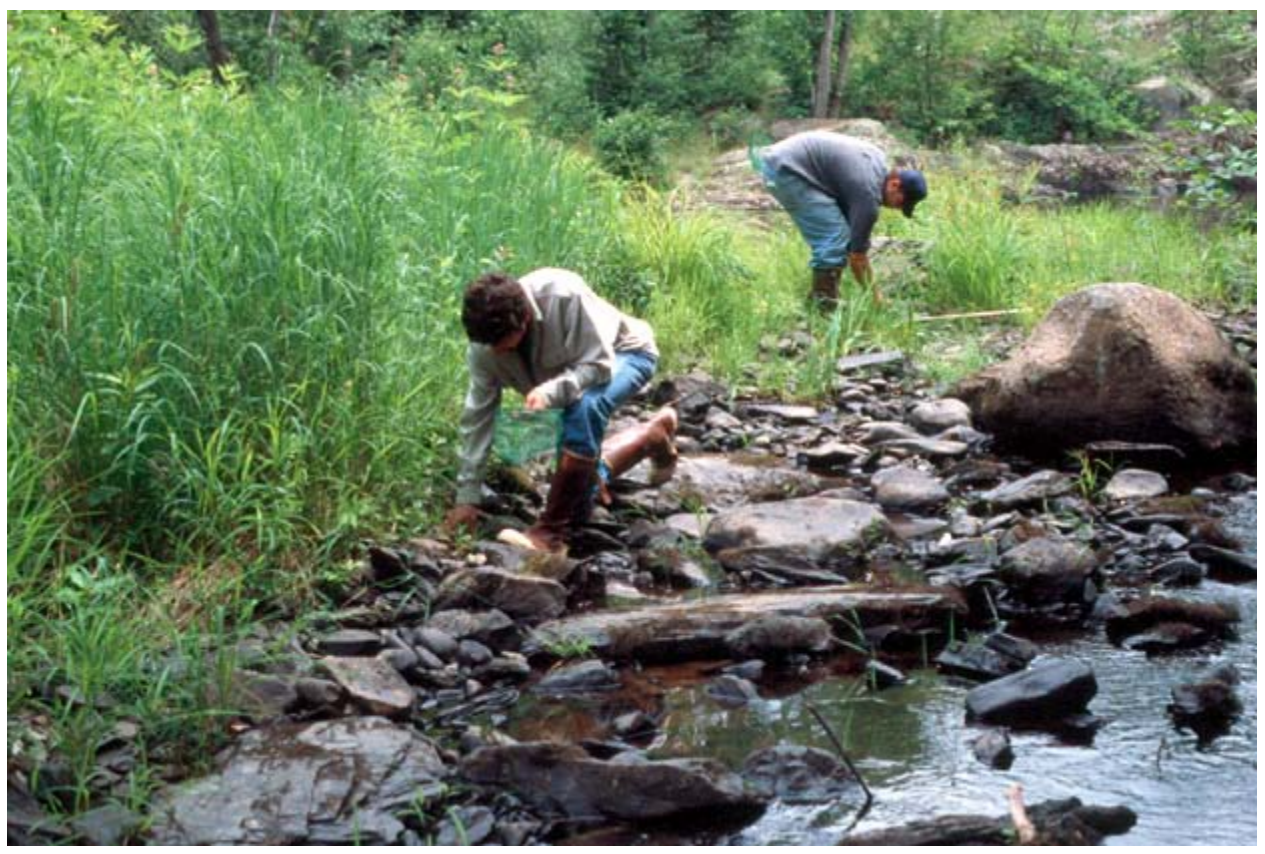

Figure 3. Time-constrained area searches along streams and other riparian habitats are a common approach to surveying for the presence of aquatic reptiles and amphibians, particularly salamanders (photo copyright by Sunkhaze Meadows National Wildlife Refuge, ME). 


\section{Road surveys}

Many reptile and amphibian species may be found crossing roads as they move through the landscape. Through the day, the road surface retains heat, which is used by these ectothermic animals to warm their bodies in preparation for normal activity. Therefore, either walking or slowly driving along these routes may be an effective way of surveying for some species. Data collected can be used to derive species lists and to estimate detectability, densities, and relative abundance measures (Burnham et al. 1980). However, some species exhibit differential use of roads, and detection of animals on roads will differ depending on specific environmental conditions. Moreover, use of roads may differ among the sexes and age groups. For example, male snakes are often more mobile and detected more readily during road surveys. Thus, road survey data may provide biased information on the sex ratios of most populations. Turtles are often detected on roads, and suffer higher mortality (Figure 4), while lizards are rarely detected because of high mobility. Generalist species are more likely to be detected on roads because of wider habitat ranges, while more specialized species may avoid roads altogether (except when roads pass through specific habitats). Physical structure of a road may affect use by various herpetofaunal species. For example, dirt roads may have higher use because they generally occur in areas of low urban impacts. Animals inhabiting areas with high density of paved road systems may experience declines because of higher road-kill mortality, and overall impacts of habitat fragmentation and urbanization (Vos and Chardon 1998).

Generally, road surveys are best used to sample reptiles and amphibians when a road is adjacent to, or bisects, a wetland or riparian habitat. Numerous amphibian species become active at night, especially after a rain event. Various reptile species are active seasonally, and during peak activity periods, numerous species may be observed crossing roads (e.g., some snakes and turtles) during the day or evening periods. Road surveys are generally not considered a good method for surveying lizard species, except possibly for some western species. Because road surveys often yield valuable information about presence of various species with minimal time and effort, it is recommended that road surveys be used when possible. However, because of the inherent biases associated with road surveys (Graeter et al. 2008), the approach is best used to augment other inventory techniques (e.g., time/ area-constrained surveys, coverboards) for purposes of general inventory efforts (e.g., development of a species list). 


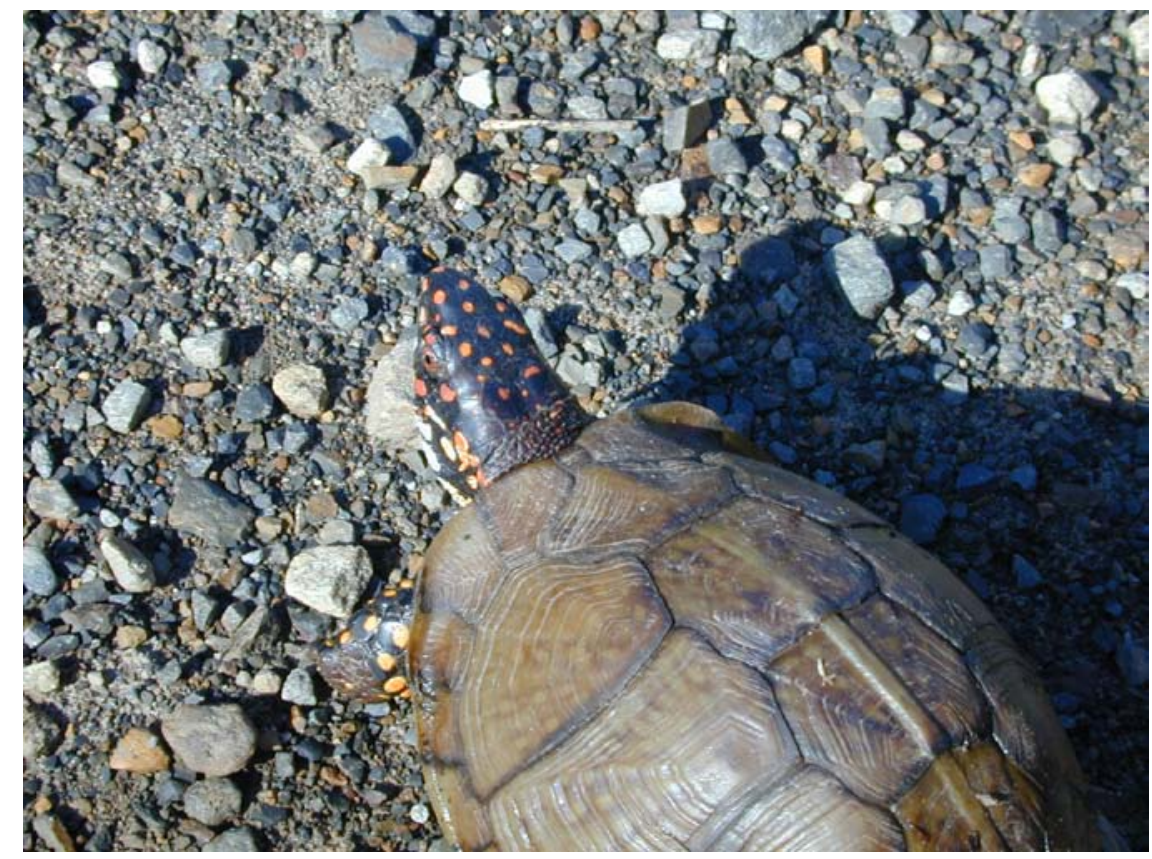

Figure 4. In many portions of the United States, many turtles, including this eastern box turtle, may be easily detected during road surveys because of their limited mobility. These species often experience higher mortality along roads than other reptiles (photo by Michael P. Guilfoyle).

Road surveys conducted on foot rather than by vehicle are often more efficient in maximizing the number and species of animals detected (Enge and Wood 2002). If road surveys are used in long-term monitoring of diversity and abundance of the herpetofaunal community, then animals may need to be captured and marked to avoid future recounting of individuals during the monitoring period (Graeter et al. 2008).

\section{Coverboard arrays}

Many herpetofaunal species use specific habitat structures for cover, such as logs and rocks, which provide opportunities to locate and document their presence. However, repeated sampling can disturb and degrade existing microhabitats and may negatively impact some sensitive populations. One option to ameliorate this problem is to create artificial cover by placement of boards (typically made of wood or plywood), metal, or plastic sheets. The use of coverboards is considered a 'passive' approach to sampling the local herpetofauna since animals are not actively searched for, but rather, coverboards are placed systematically through an area, and checked periodically (e.g., one end of the board is lifted to observe any animals that are using the board for shelter). After the initial time and cost investment of establishing coverboard arrays through a designated habitat 
or area, the sampling effort is generally less than time- area-constrained searches. Depending on objectives of the inventory/monitoring effort, the animals detected can simply be identified and the board replaced to its original position, or the animals may be captured and processed for recording pertinent population data (e.g., age, sex, reproductive status, etc.). The success of coverboards to attract use by animals is variable, but in situations where successful, the time involved during the monitoring effort is spent identifying and processing the animals rather than in searching for them. If data are to be used to estimate population size, then captured animals must be marked to determine number of subsequent recaptures (see Krebs (1989) and Skalski and Robson (1992)).

Establishing coverboard arrays is generally less expensive and time consuming then establishing pitfall traps and drift arrays. In addition, the boards are used by animals and do not trap animals; therefore, there is little or no mortality associated with the use of coverboards. The use of coverboards virtually eliminates observer bias inherent in time-/ areaconstrained searches, and local microhabitats are not degraded (Graeter et al. 2008); however, it is possible that an animal using a coverboard may vacate the areas before being detected. Coverboards usually attract certain species within a few months after placement (Fitch 1992; Grant et al. 1992; Parmelee and Fitch 1995) and are effective in documenting the presence of secretive snakes and amphibians. However, coverboards often do not sample frog and lizard populations effectively, plus capture rates and diversity measures are generally less than that of pitfall traps and drift fence arrays. As with other sampling methods, numbers of species detected under coverboards will be affected by many environmental conditions, including time of day, season, weather conditions, etc. Therefore, consistent standardized protocols must be detailed before establishing coverboard arrays, including the nature of the coverboard material, size, and placement strategy (e.g., boards placed along a transect, in a grid system, or web arrays). Design of coverboard arrays will depend upon the objectives of the study and size of the area and/ or habitats being sampled.

Specific formulas of sample sizes needed to meet study objectives can be found in the literature (see Krebs (1989) and Skalski and Robson (1992)). The removal or retention of litter under the coverboards is decided by the researcher (some snakes may use coverboards more often if litter is retained) (Parmelee and Fitch 1995), but should remain consistent for all coverboards used during the inventory and monitoring effort. Use of a 
rake or commercially produced snake hook permits the lifting of the board towards the researcher, thereby always keeping the board between the researcher and any potentially venomous or noxious animal (Graeter et al. 2008).

\section{Pitfall traps and terrestrial drift fences}

Pitfall traps and associated terrestrial drift fences (Figures 5 and 6) constitute another passive sampling method. This method involves burying a cup or bucket in the ground so that the top of the bucket is flush with the ground level. Pitfalls may be placed along natural travel routes (i.e., logs, rock ledges, pond edges, etc.) or may be placed in a pattern with drift fencing acting buried between buckets to assist in funneling animals to the pitfalls. Some trap systems include a long fence in a straight or arched shape around a wetland or pond, with trap buckets located at regular intervals and at the ends of the fence. In terrestrial settings, a ' $Y$ '-shaped system is often used (Figure 6); however, numerous different shapes and approaches may be used depending on the habitat conditions or specific traits of targeted animals. Fences are generally composed of 50-cm wire

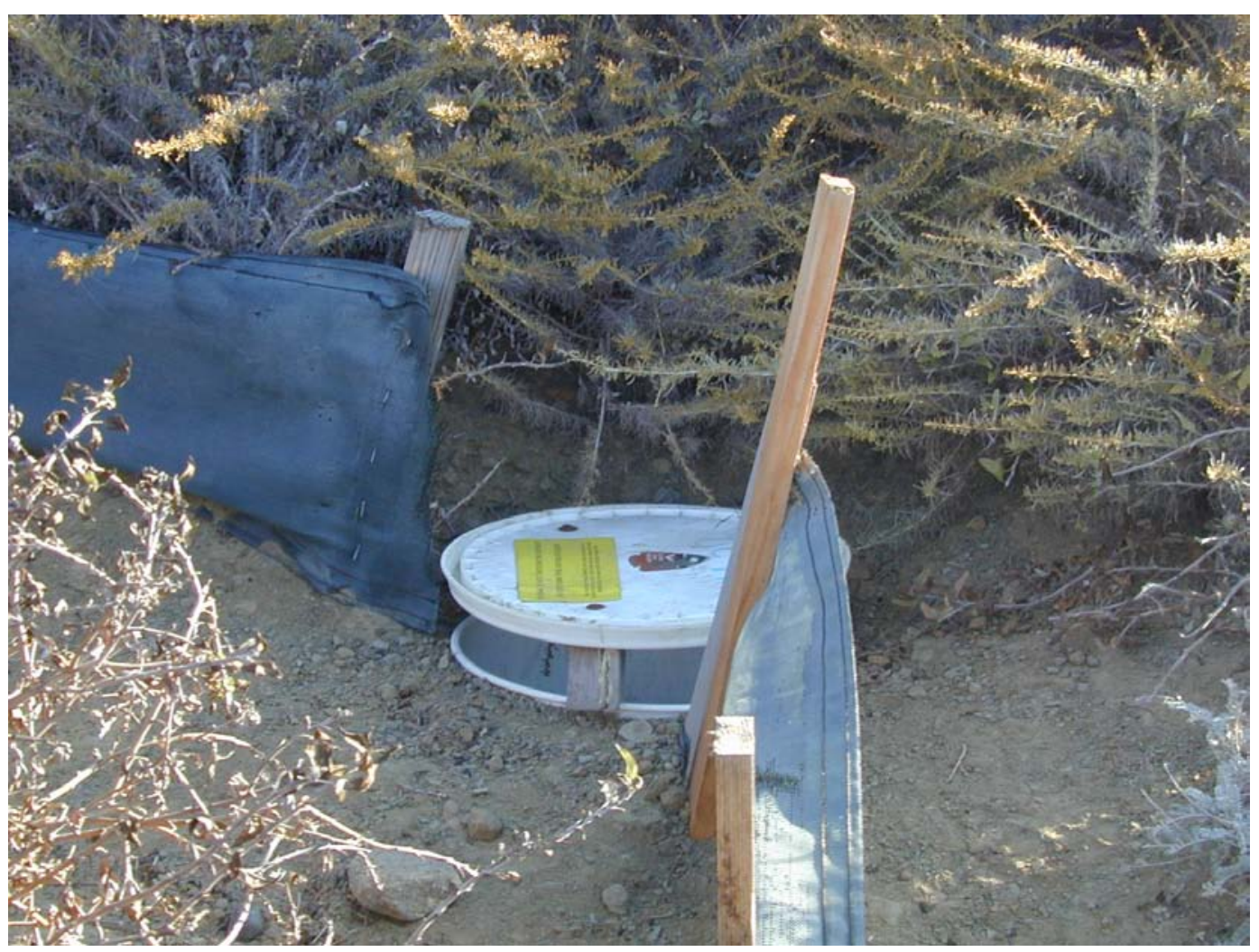

Figure 5. A pitfall trap and associated drift fence station; one of multiple stations established at the Cabrillo National Monument, Point Loma, CA, as part of a long-term herpetofaunal community monitoring program (photo by Michael P. Guilfoyle). 


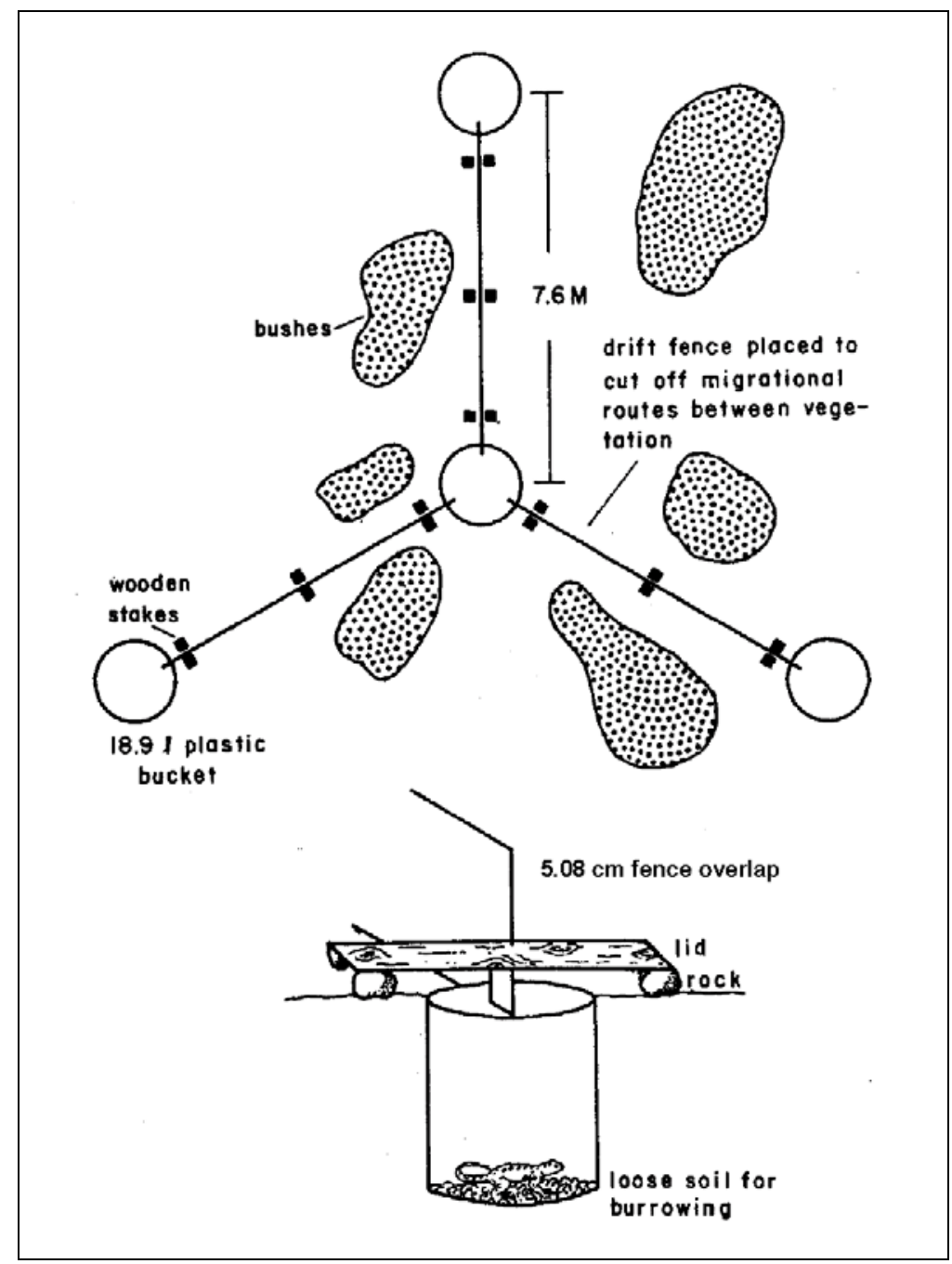

Figure 6. A typical pitfall trap and drift fence station used to capture terrestrial reptiles and amphibians (adapted from Jones (1986),

Figure 12, page 284).

mesh or aluminum flashing, but can be constructed from a variety of materials including plastic fencing or hardware cloth. The trap system can be 'closed' when not in use (e.g., lids are placed on the cups or buckets), and opened during the evening hours to be checked the following morning or left for several days (traps should not be open and left unchecked for more than $48 \mathrm{hr}$ to minimize animal mortality).

To avoid desiccation of trapped animals, a small amount or water in the bottom of the trap, or the placement of a wet sponge or towel may be needed (Graeter et al. 2008). A raised cover, especially in open sunlight conditions, may be necessary to minimize evaporation of water within the traps and to further minimize desiccation of trapped animals (Figures 5 and 6). Chicken wire or other mesh materials may be used to construct 
funnel traps (Figure 7) that are often used in association with pitfall trap and fence systems to enhance the probability of capturing larger snakes that may be missed by (or be able to escape from) the pitfall traps. Captured animals are then identified and processed (e.g., sex, age and other pertinent information collected, and/ or tagged), and then released in the vicinity where captured. Further details of establishing pitfall trap and drift fence systems can be found in Gibbons and Semlitsch (1981) and Todd et al. (2007).

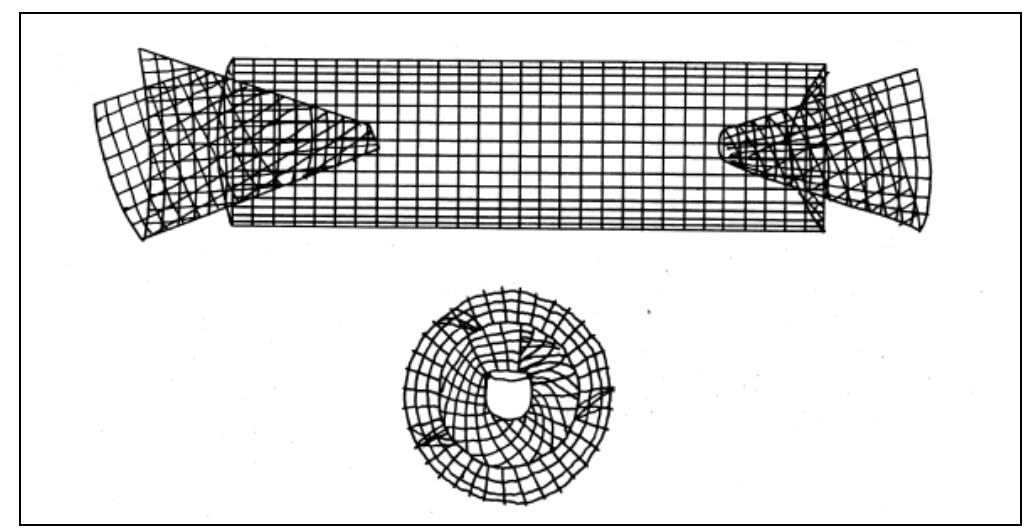

Figure 7. An example of a wire mesh funnel trap, typically placed along a drift fence to capture large snakes, or other species that may be missed by (or can escape from) the pitfall traps (adapted from Jones (1986), Figure 6, page 280).

In general, pitfall traps and drift fences are very useful in evaluating diversity and relative abundance of herpetofaunal communities. Pitfall traps and drift fences provided more species and individuals than coverboards and timed area searches in some terrestrial habitats (Ryan et al. 2002). However, mortality, including non-targeted animals, can be a frequent result of pitfall traps. Some snakes, frogs, and lizards may be able to climb or hop out of the traps; therefore, relative abundance of species from pitfall trap monitoring may be biased. The primary drawback to using pitfall traps and drift fences is the large amount of time and materials needed to establish the trapping stations. Costs of time and effort typically reduce the area that can be monitored using this approach. However, after the initial investment of time and labor in establishing the pitfall array, the stations can be maintained with a minimal amount of effort. In addition to effectively sampling the herpetofauna, pitfall arrays can be very efficient to survey small mammals and terrestrial invertebrates. Thus, these traps allow for multiple groups to be surveyed with no additional effort required, thereby maximizing the return on investment cost and effort. 


\section{Aquatic and wetland reptiles and amphibians}

\section{Seining, dipnetting and sweep samples}

Generally, the use of seines and dipnets is more common for sampling freshwater fish populations, yet when used near pond and lake shorelines, it is an effective method for inventorying and monitoring adult and juvenile amphibians (Figure 8) in pond, stream, river, and other riparian and wetland habitats (Graeter et al. 2008; USGS 2008). Seines are useful for detecting species missed by other sampling methods, while smaller hand-held dipnets are typically used to sample the eggs and larvae of salamanders and frogs (USGS 2008).

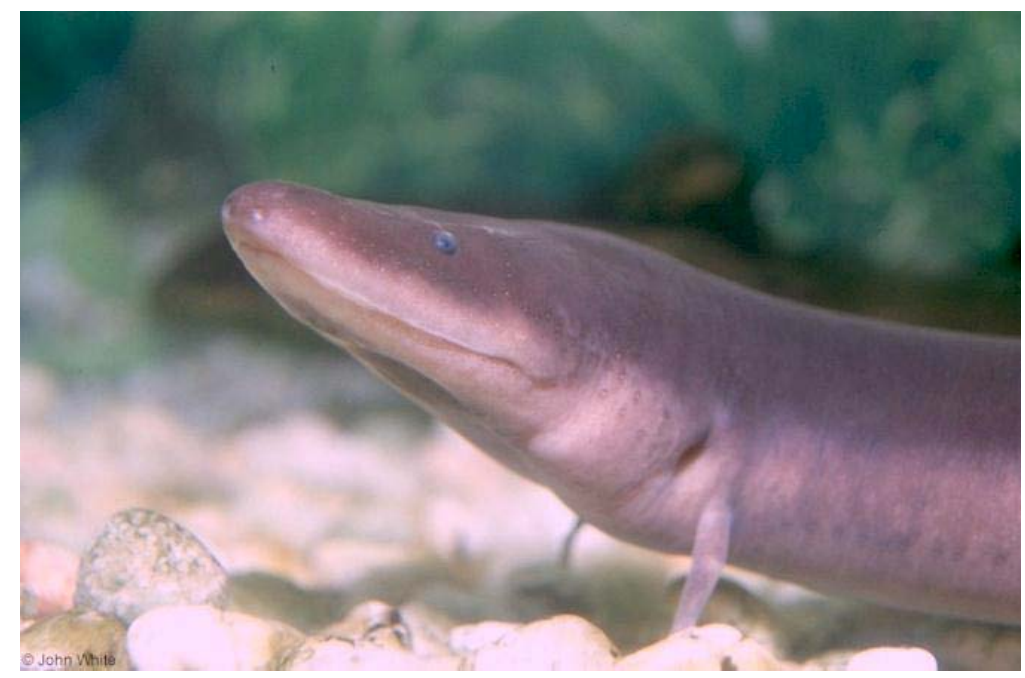

Figure 8. The two-toed amphiuma is a large aquatic amphibian present in many pond and lake habitats in the southeastern United States. Typically unnoticed by most inventory and monitoring techniques, this species may be detected through the use of a seine or dipnet along the muddy shoreline (photo by John White).

Careful attention must be placed on a standardized number of seine samples, or dipnet sweeps for long-term monitoring and statistical comparison purposes among habitat types or areas; it is essential to implement equal sampling efforts during repeated sampling periods over seasons and/ or years. Trial and error may be necessary to determine the seine and/ or dipnet mesh dimensions needed to maximize the number and diversity of specimens (Graeter et al. 2008). Seine and dipnet sampling is particularly useful in documenting the reproductive activities of amphibians in an area or habitat. Minnow traps can also be used with similar results (Smith et al. 2006). For this purpose, samples from seines and dipnets must be collected during peak periods of egg or larval stage of targeted animals. A goal 
of these techniques is to be as thorough as possible; therefore, maximizing the number of microhabitats sampled in an area is recommended. In stream systems, several researchers can kick the stones and stream bottom structure to flush animals into a downstream seine or net: this method is called 'kick sampling' and may be useful under some circumstances. A less disruptive approach may include regular shoreline surveys to document observed larvae and egg masses of targeted species. In general, the utility of data from seine and dipnet sampling efforts declines with increasing size, depth, and complexity of the wetland or riparian area being sampled (Graeter et al. 2008).

\section{Auditory surveys}

During breeding seasons, males of various frog species utter conspicuous and speciesspecific vocalizations that are readily identifiable by trained personnel or volunteers (Graeter et al. 2008; USGS 2008) (Figure 9). This behavioral characteristic permits frogs to be surveyed via point counts in a way similar to bird surveys. The North American Amphibian Monitoring Program (NAAMP) has developed a standardized method for monitoring vocalizing anurans under various habitat conditions (Weir and Mossman 2005). The general approach involves the establishment of 10 randomly placed stations near potential breeding habitat. An observer

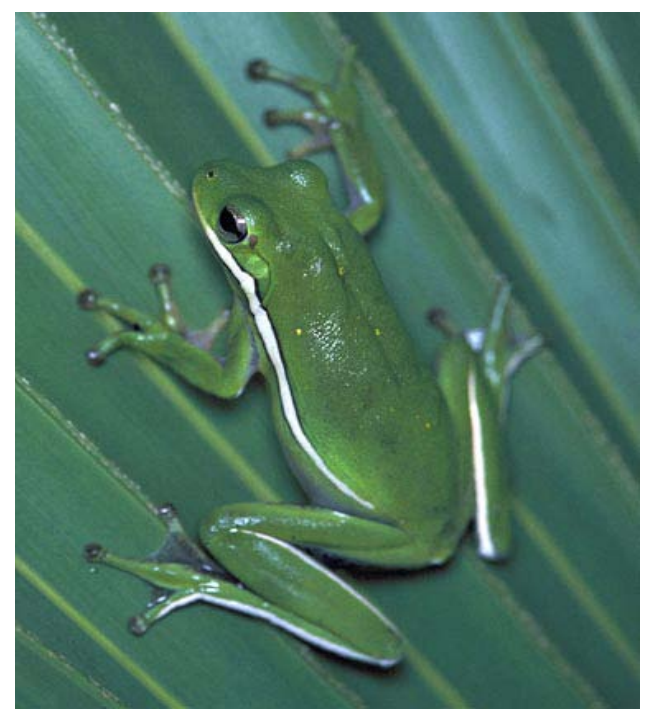

Figure 9. The green treefrog is a highly vocal species easily detected through auditory surveys in the eastern United States (photo by Jane M. Rohling, U.S. Fish and Wildlife Service). records all anuran calls during a 5-minute survey. Additional data include time, wind, and sky conditions, species and number of individuals present, and any other factor worth noting (e.g., excessive wind, traffic, etc.). These survey stations are sampled three times during the breeding season. A more detailed description of this method can be found at http://www.pwrc.usgs.gov/naamp. This method is described, and sample data sheets are provided by Graeter et al. (2008).

This approach is limited to sampling anurans; these species show considerable variation in calling frequency and amplitude of the call, therefore, detectability differences can bias monitoring data. In some circumstances, large numbers of calling frogs can occur at such intensity that 
population abundance measures become difficult to estimate accurately (Graeter et al. 2008). While detectability estimates can be calculated and density estimates produced for many species (similar to how birds are sampled), frog surveys can be more complex and trends are not as easy to interpret. This method is probably best used to determine presence/ absence of various frog species that might be missed using other methods.

\section{Basking surveys and traps}

Turtles and some snakes commonly bask on logs, rocks, and other surfaces near the edges of aquatic habitats to meet thermoregulatory requirements (Figure 10). This behavior allows surveys of basking turtles and/ or snakes to effectively inventory streams or large rivers. Basking surveys are easy to implement and only need a pair of binoculars and a small boat or canoe, and a standardized approach for moving down a stream or river to identify the animals. Basking surveys can also

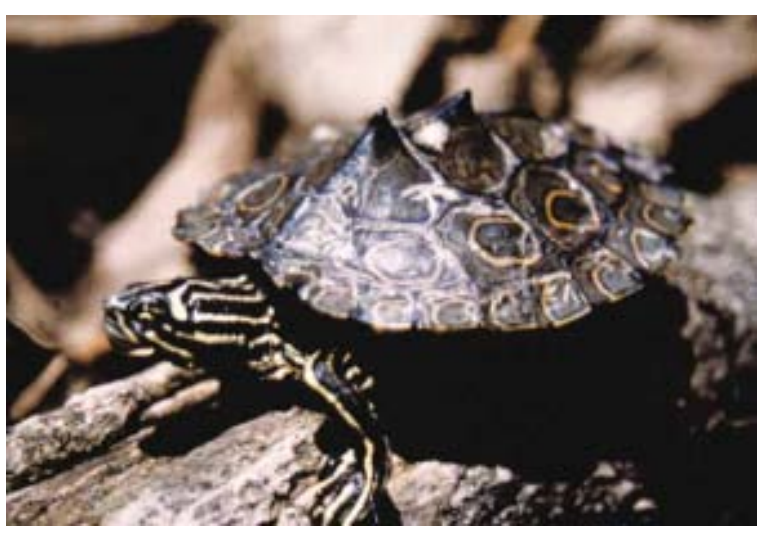

Figure 10. The Ringed Map Turtle is a riverine turtle species that can be best detected by conducting basking surveys along rivers (photo by Dena Dickerson). be conducted on foot by walking at a steady pace along a river's edge, or a pond or lake shoreline. The utility of a basking survey requires that sufficient basking structures exist for use by target species. Standard approaches should include specific seasons and weather conditions under which the surveys can be best performed for a given area or region (Graeter et al. 2008).

Basking surveys have some limitations. For example, some species are wary (e.g., some map turtles) and will regularly drop into the water before a correct species identification can be made. These wary species may require the use of a spotting scope rather than binoculars during basking surveys. Other species may show distinct behavioral differences between males and females, where females may be disproportionately present in the data because of specific basking needs of the females to meet thermoregulation requirements for egg production (Buhlmann and Vaughan 1991; Graeter et al. 2008).

If additional data are required for some turtle species, such as population size, overall health of population, or reproductive condition, the turtles 
may need to be captured and the data collected from live specimens. Basking traps, hoop nets, and Fike traps can be employed to capture turtles and are typically used along with mark-recapture studies (see Chapter 4, "Marking Techniques for Captured Herpetofaunal Species," p. 25). Basking traps are typically made from chicken wire and are placed at the water's surface and attached to a known basking log or rock. Turtles that fall into the basking trap can then be removed for data collection. If a researcher cannot be present to observe the trapping, then the basking trap should be designed for the turtle to be able to climb out; otherwise, any turtle captured in the trap may drown (Graeter et al. 2008). When capturing turtles with other traps, it is important to remember that turtles need to breathe air, so the trap needs to be set to allow captured turtles to breathe. Modified hoop-nets used to capture fish include a turtle exclusion feature that allows captured turtles to escape (Fratto et al. 2008). While this modification lowers turtle mortality, use of this device for turtle surveys necessitates that the traps be checked frequently (within $48 \mathrm{hr}$ ) to record captured turtles. See Graeter et al. (2008) for specific information and design of basking and aquatic traps and trapping techniques, placement, and monitoring protocols.

\section{Other notable inventory methods for specific target species}

\section{Sea turtles}

The Corps of Engineers manages numerous projects along coastal and riverine areas in the continental United States. Coastal beach nourishment projects are frequently under Corps oversight and assessing the use of beach habitats by nesting sea turtles may be required. Beaches known to support nesting sea turtles may be monitored by placing permanent markers in the sand approximately every $15 \mathrm{~m}$; all turtle beach nesting activities are then related back to the marker positions as reference points. During the early part of the peak breeding season, beaches may be surveyed for nesting activity by sea turtles. Once a nesting turtle has been documented, the turtle may be handled to collect important health and population data. The nest site is marked and monitored during the season. Later in the season, surveys are conducted during the day and any predation or emergence of young (as indicated by empty shells) is documented. When possible, rates of nest predation and/ or failure are recorded to estimate overall nest success rate for a species. More detailed methods concerning sea turtle surveys, including tagging and radio telemetry 
efforts, can be found in USFWS (2008b), Hillis-Starr and Phillips (2008), and Shanker et al. (2003).

The Corps of Engineers is also responsible for channel maintenance and dredging operations of many ports and inlets along the coastal areas of the United States, particularly the intracoastal waterways. Moreover, this effort entails the planning and proper deposition of dredged material, either into certified confined disposal facilities (CDFs), beach nourishment projects, or in the creation of dredged material islands. During dredging operations, particularly during use of a hopper dredge, sea turtles can be killed or injured when entrained by the suction of the dredge. Species most impacted by dredging include the loggerhead, green, Atlantic ridley, leatherback, and the hawksbill sea turtle. Therefore, the Corps is typically responsible for trawling channels for sea turtles to determine presence/ absence information, and to communicate this information to dredging operations. Furthermore, by monitoring sea turtle relative abundance, behavior, and dispersal abilities, and by modifying dredging operations, negative impacts on sea turtles from dredging activities have significantly decreased over the past 20 years (Dickerson et al. 2004). Due to these efforts by the Corps, changes have been implemented in dredging protocols, including the establishment of environmental windows (i.e., the best period to dredge while minimizing impacts on turtles), and structural changes to the hopper dredge (e.g., draghead modifications and draghead turtle deflectors) (Dickerson et al. 2004). The Corps has established a data warehouse on sea turtle presence and mortality occurring on Corps operations nationally (http://el.erdc.usace.army.mil/seaturtles/index.cfm).

\section{American alligator and American crocodile}

The Corps of Engineers is involved in managing and overseeing restoration efforts for the Everglades in southern Florida. Two specific reptile species, the American Alligator and American Crocodile (Figure 11), can be surveyed using a variety of methods. Current survey efforts include the use of a small boat along established transects through a significant portion of the breeding habitat. The boat moves slowly along the transect allowing two observers to detect the presence of either alligators or crocodiles by using a spotlight to observe reflections from the animal's eyes. Depending upon objectives of the research, the reptiles can then be captured, measured, weighed, sexed, and tagged. Alligators are also large enough with conspicuous nesting sites, so that aerial surveys can be conducted by fixed-winged aircraft or helicopter (Graeter et al. 2008). 


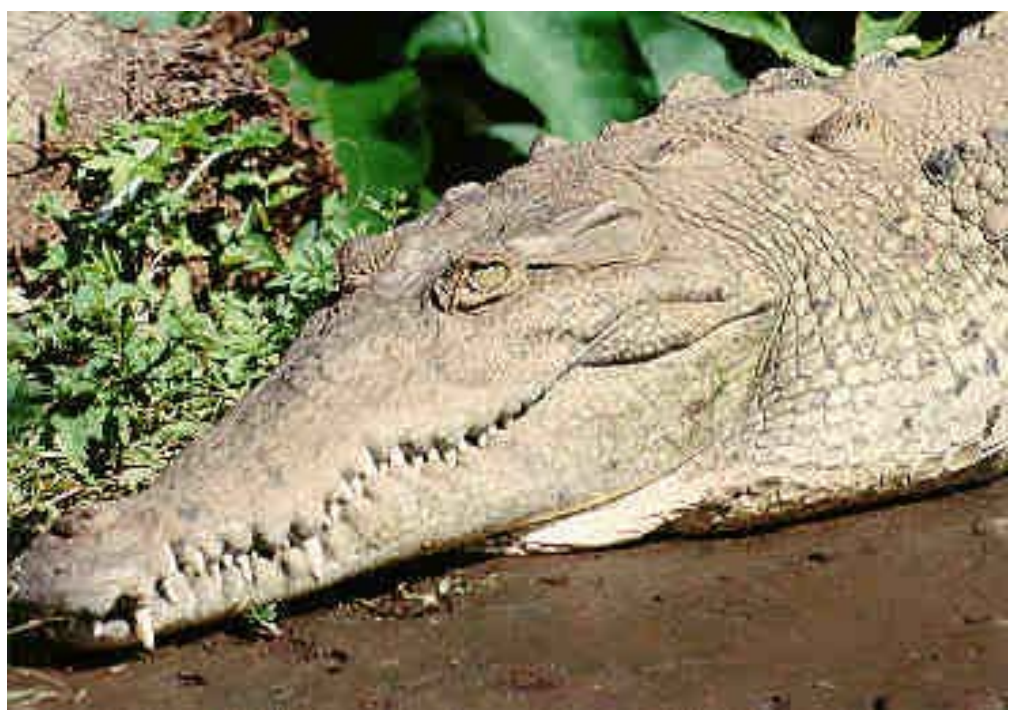

Figure 11. The American crocodile is a threatened reptile monitored by funding from the Corps of Engineers in the southern Everglades,

FL. This species is typically surveyed using evening transect counts by boat ( $p$ hoto and copyright by Julio Caballeros Sigma).

Other miscellaneous techniques

Only commonly used inventory techniques are summarized in this technical report. Numerous other techniques are available for surveying specific herpetofaunal groups or species in rare circumstances. For example, snorkeling surveys in Appalachian mountain streams have been used to survey hellbenders; snorkeling may also inventory numerous other turtles and Ambystoma salamanders missed by other inventory methods (Graeter et al. 2008). Snorkeling surveys are best applied in clear river, pond, or lake habitats. PVC pipes placed into the ground, or mounted in a tree (hardwood species provide better data than pines) have been used to attract and inventory Hylid tree frogs in eastern forest habitats (Boughton and Staiger 2000; Zacharow et al. 2003). 


\section{Marking Techniques for Captured Herpetofaunal Species}

During surveys, captured animals may have to be marked to allow recapture data to be used to estimate population size (see Krebs (1989) or Skalski and Robson (1992)). Numerous techniques are available to harmlessly and painlessly clip toes (e.g., lizards), scales (e.g., snakes), or plastrons (e.g., turtles) in specific patterns to easily identify recaptured individuals (Figure 12). More detailed descriptions on methods to mark or tag reptile and amphibian species can be found in Graeter et al. (2008). Such intensive monitoring of reptile and amphibian populations will likely require state and federal permits (see "Permit requirements" in Chapter 2 (p. 10)).

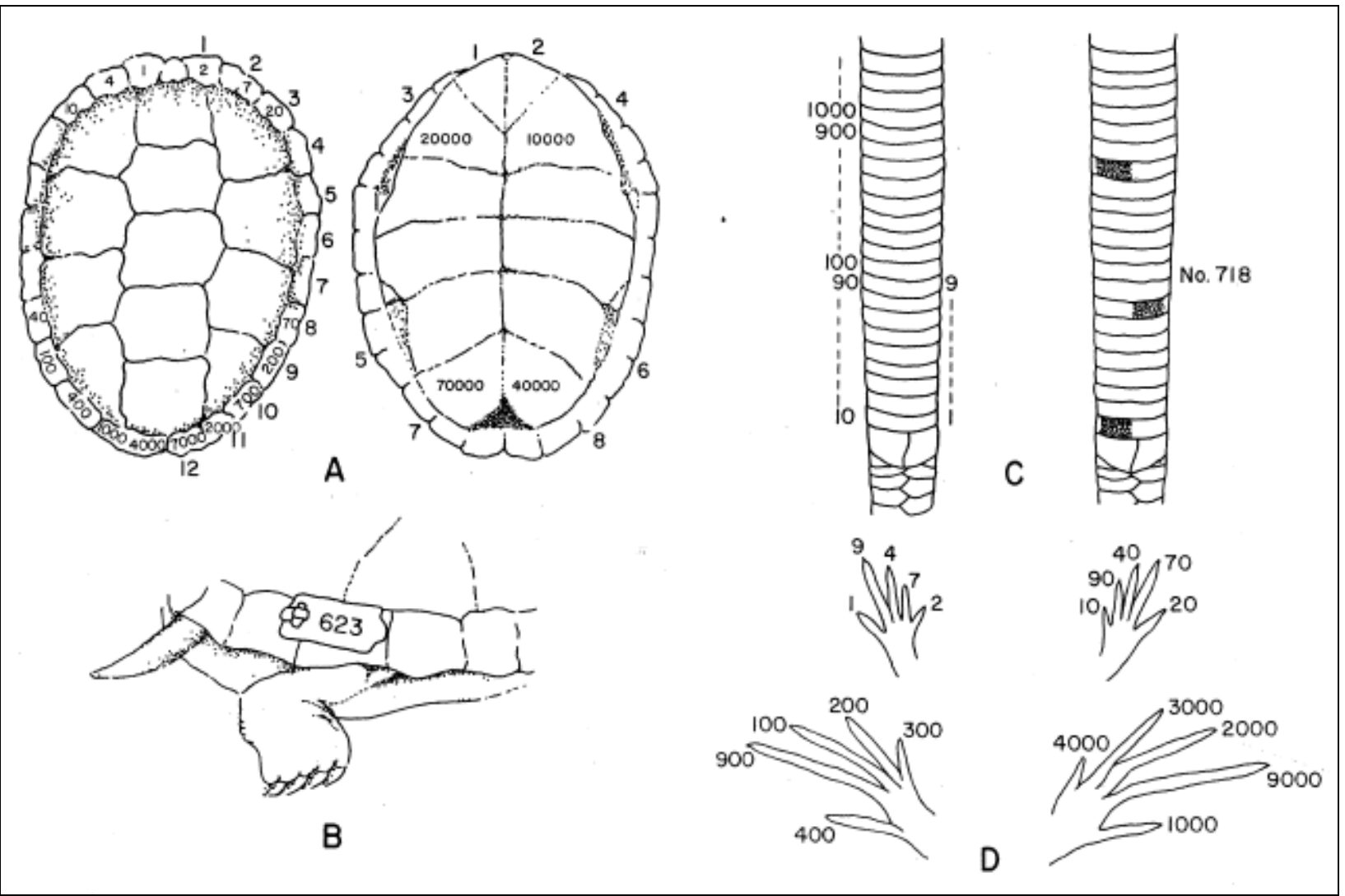

Figure 12. Examples of marking techniques for snakes, turtles, lizards, and some amphibians that may be used to identify recaptures during monitoring of reptiles and amphibians with pit fall traps and associated drift fences, or other methods. If done correctly, these techniques are harmless and painless to the animals (adapted from Jones (1986), Figure 14, page 287). 


\section{Summary}

Herpetofaunal species include reptiles and amphibians such as snakes, lizards, turtles, alligators, frogs, and salamanders. Until relatively recently, these animals were either neglected or targeted for eradication in federal land management planning. With increased awareness and education, these animals are now recognized for their valuable contributions to our nation's natural diversity and the important role they play in ecological systems. Because of their sensitivity and susceptibility to human land-use disturbances and contaminants, these animals can serve as excellent barometers of overall ecological health for specific regions, areas, or habitat types. For all these reasons, and for purposes of legal and regulation compliance, the Corps of Engineers is engaged in increasing efforts to inventory and monitor these animals on project lands. This technical note provides an overview of standard methods to detect and observe these organisms, and summarizes the number and distribution of federal/ state listed threatened and endangered reptiles and amphibians documented within seven Corps Divisions and associated Districts (see Table 1). An introduction to setting goals and objectives for inventory and monitoring programs is provided, followed by brief descriptions of the primary techniques for attaining Level II surveys on Corps of Engineer project lands, or other areas under Corps jurisdiction. Techniques focus on terrestrial and aquatic reptiles and amphibians and include (1) time-/areaconstrained searches, (2) road surveys, (3) coverboard arrays, (4) pitfall traps and terrestrial drift fences, (5) seining, dipnetting, and sweep samples, (6) auditory surveys, and (7) basking surveys and traps. Finally, methods to survey and monitor other notable species, including sea turtles, alligators, and crocodiles are summarized. 


\section{References}

Allen, C. R., K. G. Rice, D. P. Wojcik, and H. F. Percival. 1997. Effects of red imported fire ant envenomation on neonatal American alligators. J ournal of Herpetology 31:318-321.

Bailey, L. L., T. R. Simons, and K. H. Pollock. 2004. Estimating site occupancy and species detection probability parameters for terrestrial salamanders. Ecological Applications 14:692-702.

Boughton, R. G., and J . Staiger. 2000. Use of PVC pipe refugia as a sampling technique for hylid treefrogs. American Midland Naturalist 144:168-177.

Buhlmann, K. A., and M. R. Vaughan. 1991. Ecology of the turtle Pseudemys concinna in the New River, West Virginia. J ournal of Herpetology 25:72-78.

Burnham, K. P., D. R. Anderson, and J . L. Laake. 1980. Estimation of density from linetransect sampling of biological populations. Wildlife Monographs 72:2-202.

Butts, S. R., and W. C. McComb. 2000. Association of forest-floor vertebrates with coarse woody debris in managed forests of western Oregon. J ournal of Wildlife Management 64:95-104.

Collins, J . T., and T. W. Taggart. 2009. Standard common and current scientific names for North American amphibians, turtles, reptiles, and crocodilians, $6^{\text {th }}$ edition. Lawrence, KA: The Center for North American Herpetology.

Conant, R., and J . T. Collins. 1998. Reptiles and amphibians: Eastern/ Central North America. Boston, MA: Peterson Field Guide Series, Houghton Mifflin Company.

Daszak, P., D. E. Scott, A. M. Kilpatrick, C. Faggioni, J . W. Gibbons, and D. Porter. 2005. Amphibian population declines at Savannah River Site are linked to climate, not chytridiomycosis. Ecology 86: 3232-3237.

Davis, D. E. 1982. Handbook of census methods for terrestrial vertebrates. Boca Raton, FL: CRC Press, Inc.

Department of the Army. 1996. U.S. Army Corps of Engineers, Project Operations: Environmental Stewardship Operations and Maintenance Policies, Regulation No. 1130-2-540. Washington, DC. http://140.194.76.129/publications/engregs/er1130-2-540/entire.pdf.

Dickerson, D. D., M. S. Wolters, C. T. Theriot, and C. Slay. 2004. Dredging impacts of sea turtles in the Southeastern USA: A historical review of protection. In Proceedings of World Dredging Congress XVII, Dredging in a Sensitive Environment. 27 September- 1 October 2004, Central Dredging Association, ISBN 90-90182446, CD-ROM.

Enge, K. M., and K. N. Wood. 2002. A pedestrian road survey of an upland snake community in Florida. Southeastern Naturalist 1:365-380. 
Fischer, R. A., and H. R. Hamilton. 1999. Esprit de Corps: Land use and water for neotropical migratory birds. Bird Conservation, Special Issue 18.

Fischer, R. A., and H. R. Hamilton. 2001. The importance of Corps of Engineers lands to migrating and breeding birds. EMRRP Technical Notes Collection. ERDC TNEMRRP-SI-20. Vicksburg, MS: U.S. Army Engineer Research and Development Center. http://el.erdc.usace.army.mil/emrrp/.

Fitch, H. S. 1992. Methods of sampling snake populations and their relative success. Herpetological Review 23:17-19.

Fratto, Z. W., V. A. Barko, P. R. Pitts, S. L. Sheriff, J. T. Briggler, K. P. Sullivan, B. L. McKeage, and T. R. J ohnson. 2008. Evaluation of turtle exclusion and escapement devices for hoop-nets. J ournal of Wildlife Management 72:1628-1633.

Gates, J . E., C. H. Hocutt, J . R. Stauffer, J r., and G. J . Taylor. 1985. The distribution and status of Cryptobranchus alleganiensis in Maryland. Herpetological Review $16: 17-18$.

Gibbons, J . W., and R. D. Semlitsch. 1981. Terrestrial drift fences with pitfall traps: An effective technique for quantitative sampling of animal populations. Brimleyana 1981:1-16.

Gibbons, J . W. 2008. Chapter 2: Amphibians and reptiles of the United States. In Inventory and monitoring: Recommended techniques for reptiles and amphibians with applications to the United States and Canada, ed. G. J . Graeter, K. A. Bulhmann, L. R. Wilkinson, and J . W. Gibbons, 19-24. Aiken, SC: PARC Technical Report.

Glennemeier, K. A., and L. J . Begnoche. 2002. Impact of organochlorine contamination on amphibian populations in southwestern Michigan. J ournal of Herpetology 36:233-244.

Goin, C. J ., O. B. Goin, and G. R. Zug. 1978. Introduction to herpetology, 3 ${ }^{\text {rd }}$ edition. New York, NY: W. H. Freeman and Company.

Graeter, G. J., K. A. Bulhmann, L. R. Wilkinson, and J. W. Gibbons. 2008. Inventory and monitoring: Recommended techniques for reptiles and amphibians with applications to the United States and Canada. Aiken, SC: PARC Technical Report.

Grant, B. W., A. D. Tucker, J . E. Lovich, A. M. Mills, P. M. Dixon, and J. W. Gibbons. 1992. The use of coverboards in estimating patterns of reptile and amphibian biodiversity. In Wildlife 2001, ed. D. R. McCullough and R. H. Barrett, 379-403. London, UK: Elsevier Science Publications.

Guillette, L. J ., and M. P. Gunderson. 2001. Alterations in development of reproductive and endocrine systems of wildlife populations exposed to endocrine-disrupting contaminants. Reproduction 122:857-864.

Heyer, W. R., M. A. Donnelly, R. W. McDiarmid, L. C. Hayek, and M. S. Foster, eds. 1994. Measuring and monitoring biological diversity: Standard methods for amphibians. Washington, DC: Smithsonian Institution Press. 
Hillis-Starr, Z., and B. Phillips. 2008. Buck Island Reef National Monument Sea Turtle Research Program: Sea turtle nesting research and monitoring program protocols manual. Gainesville, FL: U.S. Geological Survey, Florida Integrated Science Center. http://fl.biology.usgs.gov/Coral_Reef_Ecology/ Buck_Is_Sea_Turtle_Protocols/buck_is_sea_turtle_protocols.html.

Hopkins, W. A., C. L. Rowe, and J . D. Congdon. 1999. Elevated trace element concentrations and standard metabolic rate in banded water snakes, Nerodia fasciata, exposed to coal combustion wastes. Environmental Toxicology and Chemistry 18:1258-1263.

Jancovich, J . A., E. W. Davidson, E. F. Morado, J . L. Bertram, and J . P. Collins. 1995. Isolation of a lethal virus from the endangered tiger salamander Ambystoma tigrinum stebbinsi. Diseases of Aquatic Organisms 31: 161-167.

Jones, K. B. 1986. Amphibians and reptiles. In Inventory and monitoring of wildlife habitat, ed. A. Y. Cooperrider, R. J . Boyd, and H. R. Stuart, 267-290. Denver, CO: U.S. Department of the Interior, Bureau of Land Management Service Center.

Krause, J., P. Peloquin, D. Wiese, and G. Swenson. 2004. Statement of need - Level One natural resource inventory. Prepared by U.S. Army Corps of Engineers Stewardship Advisory Team, Stewardship Support Program, for Headquarters Natural Resources Management.

Krebs, C. J . 1989. Ecological methodology. New York, NY: Harper Collins Publishers.

Maisonneuve, C, and S. Rioux. 2001. Importance of riparian habitats for small mammal and herpetofaunal communities in agricultural landscapes of southern Quebec. Agriculture, Ecosystems and Environment 83:165-175.

Martin, C. O. 2009. Mammalian survey techniques for Level II natural resource inventories on Corps of Engineer projects, Part I. EMRRP Technical Notes Collection. ERDC TN-EMRRP-SI-34. Vicksburg, MS: U.S. Army Engineer Research and Development Center. http://el.erdc.usace.army.mil/emrrp/.

Martin, C. O., J. Krause, and D. N. Wiese. 2006. Natural resources level one inventories: What are the needs and process for Corps projects? EMRRP Technical Notes Collection. ERDC TN-EMRRP-EM-04. Vicksburg, MS: U.S. Army Engineer Research and Development Center. http://el.erdc.usace.army.mil/emrrp/.

Operations and Management Business Information List (OMBIL). 2008. Environmental Stewardship, Business Functional Reports: Project Site Special Status Species Report for Fiscal Year 2007.https://ombil.usace.army.mil/MainFrames/ BusinessFrame.htm. (7 Aug. 2009).

Parmelee, J . R., and H. S. Fitch. 1995. An experiment with artificial shelters for snakes: Effects of materials, age, and surface preparations. Herpetological Natural History 3:187-191.

Ryan, T. J ., T. Philippi, Y. A. Leiden, M. E. Dorcas, T. B. Wigley, and J. W. Gibbons. 2002. Monitoring herpetofauna in a forested landscape: Effects of habitat types and census techniques. Forest Ecology and Management 167:83-90. 
Shanker, K., B. Pandav, and H. V. Andrews. 2003. Sea turtle conservation: Research and management techniques. A GOI-UNDP Project Manual. Mamallapuram, Tamil Nadu, India: Centre for Herpetology/ Madras Crocodile Bank Trust.

Skalski, J . R., and D. S. Robson. 1992. Techniques for wildlife investigations: Design and analysis of capture data. San Diego, CA: Academic Press.

Smith, L. L., W. J . Barichivich, J . S. Staiger, K. G. Smith, and C. K. Dodd, Jr. 2006. Detection probabilities and site occupancy estimates for amphibians at Okefenokee National Wildlife Refuge. American Midland Naturalist 155:149-161.

Smith, R. B., R. A. Seigel, and K. A. Smith. 1998. Occurrence of upper respiratory tract disease in gopher tortoise populations in Florida and Mississippi. J ournal of Herpetology 32:426-430.

Stebbins, R. C. 1985. Western reptiles and amphibians. Peterson Field Guide Series. New York, NY: Houghton Mifflin Company.

Todd, B. D., C. T. Winne, J . D. Willson, and J . W. Gibbons. 2007. Getting the drift: Effects of timing, trap type, and taxon on herpetofaunal drift fence surveys. American Midland Naturalist 158:292-305.

Unrine, J . M., C. H. J agoe, C. Brinton, H. A. Brant, and N. T. Garvin. 2005. Dietary mercury exposure and bioaccumulation in amphibian larvae inhabiting Carolina bay wetlands. Environmental Pollution 135:245-253.

U.S. Army Corps of Engineers (USACE). 2005. USACE Threatened, Endangered, and Sensitive Species Protection and Management System: Species Information. http://el.erdc.usace.army.mil/tessp/list.cfm?Code=District\&Step=2\&Type=SAD. (8 Sept. 2008).

U.S. Congress. 1944. Flood Control Act of 1944. (Public Law 78-534), Section 4, 78 th Congress, (58 Stat. 889, 16 U.S.C. 460-b). December 22, 1944. Washington, D.C.

U.S. Fish and Wildlife Service (USFWS). 2008a. Threatened and Endangered Species Program. http://www.fws.gov/endangered/wildlife.html\#Species (15 Aug. 2008).

U.S. Fish and Wildlife Service (USFWS). 2008b. Alabama Sea Turtle Conservation Manual. Gulf Shores, AL: Department of the Interior, U.S. Fish and Wildlife Service, Bon Secour National Wildlife Refuge. http://www.alabamaseaturtles.com/ASTconservationmanual.pdf.

U.S. Geological Survey (USGS). 2008. Amphibian Research and Monitoring Initiative (ARMI): Program background and design. http://armi.usgs.gov/programbackground.asp\#amphibianmonitoring. 15 Dec. 2008.

Vos, C. C., and J . P. Chardon. 1998. Effects of habitat fragmentation and road density on the distribution pattern of the moor frog, Rana arvalis. J ournal of Applied Ecology 35:44-56.

Weir, L. A., and M. J . Mossman. 2005. North American Amphibian Monitoring Program (NAAMP). In Amphibian declines: Conservation status of United States species, ed. M. J. Lannoo, 307-313. Berkeley, CA: University of California Press. 
Zacharow, R. T., W. J . Barichivich, and C. K. Dodd, Jr. 2003. Using ground-placed PVC pipes to monitor hylid treefrogs: capture bias. Southeastern Naturalist 2:575590 . 


\section{Appendix A: Common and Scientific Names}

Common and scientific names of all amphibians and reptiles (from Collins and Taggart 2009) noted in this technical report.

\begin{tabular}{|c|c|}
\hline Common Name & Scientific Name \\
\hline \multicolumn{2}{|c|}{ Class Amphibia } \\
\hline Western Toad & Bufo boreas \\
\hline Oak Toad & Bufo quercicus \\
\hline Woodhouse's Toad & Bufo woodhousii \\
\hline Barking Frog & Craugaster augusti \\
\hline Blanchard's Cricket Frog & Acris blanchardi \\
\hline Green Treefrog & Hyla cinerea \\
\hline Barking Treefrog & Hyla gratiosa \\
\hline Illinois Chorus Frog & Pseudacris streckeri illinoensis \\
\hline Midland Chorus Frog & Pseudacris triseriata \\
\hline Northern Crawfish Frog & Lithobates areolatus circulosus \\
\hline Carolina Gopher Frog & Lithobates captio \\
\hline Bullfrog & Lithobates catesbeianus \\
\hline Northern Leopard Frog & Lithobates pipiens \\
\hline Wood Frog & Lithobates tarahumarae \\
\hline Northern Red-legged Frog & Rana aurora \\
\hline Foothill Yellow-legged Frog & Rana boylii \\
\hline California Red-legged Frog & Rana draytonii \\
\hline Columbia Spotted Frog & Rana luteiventris \\
\hline Sierra Madre Yellow-legged Frog & Rana muscosa \\
\hline Oregon Spotted Frog & Rana pretiosa \\
\hline Hurter's Spadefoot & Scaphiopus hurterii \\
\hline California Tiger Salamander & Ambystoma californiense \\
\hline Jefferson Salamander & Ambystoma jeffersonianum \\
\hline Blue Spotted Salamander & Ambystoma laterale \\
\hline Mabee's Salamander & Ambystoma mabeei \\
\hline Sonoran Tiger Salamander & Ambystoma mavortium stebbinsi \\
\hline
\end{tabular}




\begin{tabular}{|c|c|}
\hline Common Name & Scientific Name \\
\hline Smallmouth Salamander & Ambystoma texanum \\
\hline Eastern Tiger Salamander & Ambystoma tigrinum \\
\hline Two-toed Amphiuma & Amphiuma means \\
\hline Hellbender & Cryptobranchus alleganiensis \\
\hline Green Salamander & Aneides aeneus \\
\hline Clouded Salamander & Aneides ferreus \\
\hline Cave Salamander & Eurycea lucifuga \\
\hline Spring Salamander & Gyrinophilus porphyriticus \\
\hline Four-toed Salamander & Hemidactylium scutatum \\
\hline Red Hills Salamander & Phaeognathus hubrichti \\
\hline Coeur d'Alene Salamander & Plethodon idahoensis \\
\hline Louisiana Slimy Salamander & Plethodon kisatchie \\
\hline Wehrle's Salamander & Plethodon wehrlei \\
\hline \multicolumn{2}{|c|}{ Class Chelonia } \\
\hline Loggerhead & Caretta caretta \\
\hline Green Turtle & Chelonia mydas \\
\hline Hawksbill & Eretmochelys imbricata \\
\hline Atlantic Ridley & Lepidochelys kempii \\
\hline Common Snapping Turtle & Chelydra serpentina \\
\hline Alligator Snapping Turtle & Macrochelys temminchii \\
\hline Leatherback & Dermochelys coriacea \\
\hline Western Pond Turtle & Actinemys marmorata \\
\hline Northwestern Pond Turtle & Actinemys marmorata marmorata \\
\hline Southwestern Pond Turtle & Actinemys marmorata pallida \\
\hline Northern Painted Turtle & Chrysemys picta \\
\hline Spotted Turtle & Celmmys guttata \\
\hline Western Chicken Turtle & Deirochelys reticularia miaria \\
\hline Eastern Chicken Turtle & Deirochelys reticularia reticularia \\
\hline Wood Turtle & Glyptemys insculpta \\
\hline Bog Turtle & Glyptemys muhlenbergii \\
\hline Blanding's Turtle & Emydoidea blandingii \\
\hline Common Map Turtle & Graptemys geographica \\
\hline Ringed Map Turtle & Graptemys oculifera \\
\hline
\end{tabular}




\begin{tabular}{|c|c|}
\hline Common Name & Scientific Name \\
\hline Ouachita Map Turtle & Graptemys ouachitensis \\
\hline False Map Turtle & Graptemys pseudogeographica \\
\hline Diamondback Terrapin & Malaclemys terrapin \\
\hline Eastern River Cooter & Pseudemys concinna \\
\hline Eastern Redbelly Turtle & Pseudemys rubriventris \\
\hline Eastern Box Turtle & Terrapene carolina carolina \\
\hline Illinois Mud Turtle & Kinosternon flavescens spooneri \\
\hline Eastern Mud Turtle & Kinosternon subrubrum subrubrum \\
\hline Razorback Musk Turtle & Sternotherus carinatus \\
\hline Flattened Musk Turtle & Sternotherus depressus \\
\hline Gopher Tortoise & Gopherus polyphemus \\
\hline Smooth Softshell & Apalone mutica \\
\hline Spiny Softshell & Apalone spiniferus \\
\hline \multicolumn{2}{|c|}{ Class Eusuchia } \\
\hline American Alligator & Alligator mississippiensis \\
\hline American Crocodile & Crocodylus acutus \\
\hline \multicolumn{2}{|c|}{ Class Reptilia } \\
\hline Northern Alligator Lizard & Elgaria coerulea \\
\hline Slender Glass Lizard & Ophisaurus attenuatus \\
\hline Blunt-nosed Leopard Lizard & Gambelia sila \\
\hline Texas Horned Lizard & Phrynosoma cornutum \\
\hline Sagebrush Lizard & Sceloporus graciosus \\
\hline Northern Sagebrush Lizard & Sceloporus graciosus graciosus \\
\hline Coal Skink & Plestiodon anthracinus \\
\hline Northern Coal Skink & Plestiodon anthracinus anthracinus \\
\hline Southern Coal Skink & Plestiodon anthracinus pluvialus \\
\hline Southeastern Five-lined Skink & Plestiodon inexpectatus \\
\hline Great Plains Skink & Plestiodon obsoletus \\
\hline Little Striped Whiptail & Aspidoscelis inornata \\
\hline Kirkland's Snake & Clonophis kirklandii \\
\hline Buttermilk Racer & Coluber anthicus \\
\hline Eastern Indigo Snake & Drymarchon couperi \\
\hline Scarlet Kingsnake & Lampropeltis triangulum elapsoides \\
\hline
\end{tabular}




\begin{tabular}{|c|c|}
\hline Common Name & Scientific Name \\
\hline Smooth Green Snake & Liochlorophis vernalis \\
\hline San Joaquin Coachwhip & Masticophis flagellum ruddocki \\
\hline Western Fox Snake & Mintonius vulpinus \\
\hline Rough Green Snake & Opheodrys aestivus \\
\hline Great Plains Rat Snake & Pantherophis emoryi \\
\hline Eastern Corn Snake & Pantherophis guttata \\
\hline Eastern Pine Snake & Pituophis melanoleucus \\
\hline Northern Pine Snake & Pituophis melanoleucus melanoleucus \\
\hline Louisiana Pine Snake & Pituophis ruthreni \\
\hline Short-tailed Snake & Stilosoma extenuatum \\
\hline Rim Rock Crowned Snake & Tantilla oolitica \\
\hline Eastern Diamondback Rattlesnake & Crotalus adamanteus \\
\hline Timber Rattlesnake & Crotalus horridus \\
\hline Prairie Rattlesnake & Crotalus viridus \\
\hline Eastern Massasauga & Sistrurus catenatus catenatus \\
\hline Midwest Worm Snake & Carphophis amoenus helenae \\
\hline Western Worm Snake & Carphophis vermis \\
\hline Western Pigmy Rattlesnake & Sistrurus miliarius streckeri \\
\hline Ringneck Snake & Diadophis punctatus \\
\hline Texas Coral Snake & Micrurus tener \\
\hline Atlantic Salt Marsh Snake & Nerodia clarkia taeniata \\
\hline Copperbelly Water Snake & Nerodia erythrogaster neglecta \\
\hline Florida Green Water Snake & Nerodia floridana \\
\hline Giant Garter Snake & Thamnophis gigas \\
\hline Eastern Ribbon Snake & Thamnophis sauritus \\
\hline Lined Snake & Tropidoclonion lineatum \\
\hline Western Hognose Snake & Heterodon nasicus \\
\hline Dusty Hognose Snake & Heterodon gloydi \\
\hline Eastern Hognose Snake & Heterodon platirhinos \\
\hline Southern Hognose Snake & Heterodon simus \\
\hline
\end{tabular}




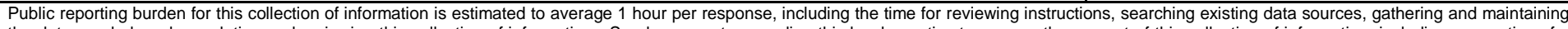

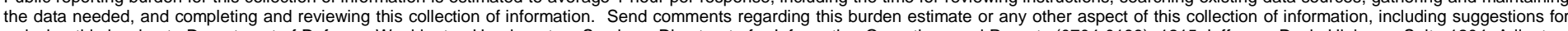

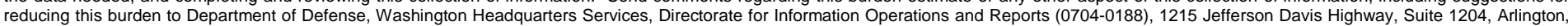

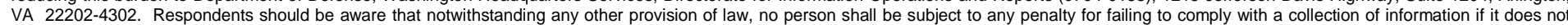
display a currently valid OMB control number. PLEASE DO NOT RETURN YOUR FORM TO THE ABOVE ADDRESS.
1. REPORT DATE (DD-MM-YYYY)
2. REPORT TYPE
3. DATES COVERED (From - To)

May 2010

Final report

\section{TITLE AND SUBTITLE}

Implementing Herpetofaunal Inventory and Monitoring Efforts on Corps of Engineers

Project Lands

5a. CONTRACT NUMBER

5b. GRANT NUMBER

5c. PROGRAM ELEMENT NUMBER

\section{AUTHOR(S)}

Michael P. Guilfoyle

5d. PROJECT NUMBER

5e. TASK NUMBER

5f. WORK UNIT NUMBER

\section{PERFORMING ORGANIZATION NAME(S) AND ADDRESS(ES)}

8. PERFORMING ORGANIZATION REPORT NUMBER

U.S. Army Engineer Research and Development Center

Environmental Laboratory

ERDC/EL TR-10-5

3909 Halls Ferry Road

Vicksburg, MW 39180-6199

9. SPONSORING I MONITORING AGENCY NAME(S) AND ADDRESS(ES)

10. SPONSOR/MONITOR'S ACRONYM(S)

Headquarters, U.S. Army Corps of Engineers

Washington, DC 20314-1000

11. SPONSOR/MONITOR'S REPORT NUMBER(S)

\section{DISTRIBUTION / AVAILABILITY STATEMENT}

Approved for public release; distribution is unlimited.

\section{SUPPLEMENTARY NOTES}

\section{ABSTRACT}

Herpetofaunal species include reptiles and amphibians such as snakes, lizards, turtles, alligators, frogs, and salamanders. These animals are recognized for their valuable contributions to the nation's natural diversity and their important role in ecological systems. The Corps of Engineers is engaged in increasing efforts to inventory and monitor these animals on project lands because of their sensitivity to human land-use disturbances and contaminants and for legal and regulatory compliance. This technical report provides an overview of standard methods to inventory and monitor these organisms, and summarizes the number and distribution of federal/state listed threatened and endangered reptiles and amphibians documented within seven Corps Divisions and associated Districts. An introduction to setting goals and objectives is provided, followed by brief descriptions of the primary techniques for attaining Level II inventories on Corps of Engineer project lands, or other areas under Corps jurisdiction. The techniques focus on terrestrial and aquatic reptiles and amphibians and include (1) Time-/Area-constrained Searches, (2) Road Surveys, (3) Coverboard Arrays, (4) Pitfall traps and Terrestrial Drift Fences, (5) Seining, Dipnetting, and Sweep Samples, (6) Auditory Surveys, and (7) Basking Surveys and Traps. Finally, methods to inventory other notable species, including sea turtles, alligators, and crocodiles are summarized.

\section{SUBJECT TERMS}

Herpetofaunal inventories

Threatened and endangered species

Herpetofaunal species

16. SECURITY CLASSIFICATION OF:

\begin{tabular}{|l|l|r|}
\hline a. REPORT & b. ABSTRACT & c. THIS PAGE \\
UNCLASSIFIED & UNCLASSIFIED & UNCLASSIFIED
\end{tabular}

17. LIMITATION OF ABSTRACT 18. NUMBER
OF PAGES

42 19a. NAME OF RESPONSIBLE PERSON

19b. TELEPHONE NUMBER (include area code) 